\title{
The Rhizobial Microbiome from the Tropical Savannah Zones in Northern Côte d'Ivoire
}

\author{
Sara Laetitia Elphège Gnangui ${ }^{1} \mathbb{D}$, Romain Kouakou Fossou ${ }^{1, *} \mathbb{D}$, Anicet Ebou ${ }^{1,2} \mathbb{D}$, Chiguié Estelle Raïssa Amon ${ }^{1}$, \\ Dominique Kadio Koua $^{2}$, Claude Ghislaine Zaka Kouadjo ${ }^{3}$, Don A. Cowan ${ }^{4}$ and Adolphe Zézé ${ }^{1}$
}

\section{check for}

updates

Citation: Gnangui, S.L.E.; Fossou, R.K.; Ebou, A.; Amon, C.E.R.; Koua, D.K.; Kouadjo, C.G.Z.; Cowan, D.A.; Zézé, A. The Rhizobial Microbiome from the Tropical Savannah Zones in Northern Côte d'Ivoire. Microorganisms 2021, 9, 1842. https://doi.org/10.3390/ microorganisms 9091842

Academic Editors: Stefano Ghignone and Franco Magurno

Received: 25 June 2021

Accepted: 21 August 2021

Published: 30 August 2021

Publisher's Note: MDPI stays neutral with regard to jurisdictional claims in published maps and institutional affiliations.

Copyright: (c) 2021 by the authors. Licensee MDPI, Basel, Switzerland. This article is an open access article distributed under the terms and conditions of the Creative Commons Attribution (CC BY) license (https:/ / creativecommons.org/licenses/by/ $4.0 /)$.
1 Laboratoire de Biotechnologies Végétale et Microbienne (LBVM), Unité Mixte de Recherche et d'Innovation en Sciences Agronomiques et Génie Rural, Institut National Polytechnique Felix Houphouët-Boigny, Yamoussoukro 1093, Côte d'Ivoire; laetitiasara1987@gmail.com (S.L.E.G.); anicet.ebou@gmail.com (A.E.); emmamon9@gmail.com (C.E.R.A.); youhedeba@gmail.com (A.Z.)

2 Équipe Bioinformatique, Département de Formation et de Recherche Agriculture et Ressources Animales, Institut National Polytechnique Félix Houphouët-Boigny, Yamoussoukro 1313, Côte d'Ivoire; dominique.koua@inphb.ci

3 Laboratoire Central de Biotechnologies, Centre National de la Recherche Agronomique, 01 Abidjan 1740, Côte d'Ivoire; claudghis@gmail.com

4 Centre for Microbial Ecology and Genomics, Department of Biochemistry, Genetics and Microbiology, University of Pretoria, Pretoria 0002, South Africa; don.cowan@up.ac.za

* Correspondence: romain.fossou@inphb.ci

Abstract: Over the past decade, many projects have been initiated worldwide to decipher the composition and function of the soil microbiome, including the African Soil Microbiome (AfSM) project that aims at providing new insights into the presence and distribution of key groups of soil bacteria from across the African continent. In this national study, carried out under the auspices of the AfSM project, we assessed the taxonomy, diversity and distribution of rhizobial genera in soils from the tropical savannah zones in Northern Côte d'Ivoire. Genomic DNA extracted from seven sampled soils was analyzed by sequencing the V4-V5 variable region of the 16S rDNA using Illumina's MiSeq platform. Subsequent bioinformatic and phylogenetic analyses showed that these soils harbored 12 out of 18 genera of Proteobacteria harboring rhizobia species validly published to date and revealed for the first time that the Bradyrhizobium genus dominates in tropical savannah soils, together with Microvirga and Paraburkholderia. In silico comparisons of different 16S rRNA gene variable regions suggested that the V5-V7 region could be suitable for differentiating rhizobia at the genus level, possibly replacing the use of the V4-V5 region. These data could serve as indicators for future rhizobial microbiome explorations and for land-use decision-making.

Keywords: african soil microbiome (AfSM) project; savannah; Bradyrhizobium; high-throughput amplicon sequencing (HTAS); 16S rDNA variable regions; V5-V7 region

\section{Introduction}

Since the advent of sequencing technologies, the determination of microbial diversity has become a major topic of interest [1]. Over the last decade, for example, many small- or broad-scales initiatives have been launched around the world to decipher the composition and function of soil microbiome [2-7], including the African Soil Microbiome (AfSM) Project implemented in Sub-Saharan Africa (SSA) [8,9]. This unique multi-national project, implemented in a dozen SSA countries, is the first such study to ever be undertaken in Africa at this scale $[9,10]$. It was launched in 2016 to provide new insights into the presence and the distribution of key groups of soil bacteria, including the rhizobia, by using the high-throughput amplicon sequencing (HTAS) and phylogeny of the 16S rRNA gene [9,10].

Rhizobia are Gram-negative saprophytic Alpha- and Beta-proteobacteria that play a key role in nitrogen biochemical cycling [11,12]. They form a polyphyletic group of bacteria among the lineages of prokaryotes capable of reducing atmospheric dinitrogen $\left(\mathrm{N}_{2}\right)$ 
into ammonia $\left(\mathrm{NH}_{3}\right)$ using their nitrogenase enzyme complex [13-15]. The symbiotic reduction of $\mathrm{N}_{2}$ by diazotrophic rhizobia happened in microoxic conditions of the mature nodule during endosymbiosis with legumes (exceptionally, with the non-legume Parasponia species) [16-18]. During the nodulation process, host plants actively screen infecting bacteria for non-compatible or hitchhiking strains via the exchange of multiple molecular signals [16-18]. In spite of such selectivity in the recruitment of symbionts, rhizobia isolated from nodules belong to remarkably diverse microbial taxa $[15,19]$. They are scattered across 18 genera in the families: Brucellaceae (genus Ochrobactrum), Devosiaceae (formely Hyphomicrobiaceae: [20,21]) (Devosia), Methylobacteriaceae (Methylobacterium, Microvirga), Nitrobacteraceae (formely Bradyrhizobiaceae: [21,22]) (Bradyrhizobium), Phyllobacteriaceae (Aminobacter, Mesorhizobium, Phyllobacterium), Rhizobiaceae [Allorhizobium, Ensifer (syn. Sinorhizobium), Neorhizobium, Pararhizobium, Rhizobium, Shinella], Xanthobacteraceae (Azorhizobium) and Burkholderiaceae (Cupriavidus, Paraburkholderia, Trinickia); the last three genera belonging to the class of Betaproteobacteria [15]. Bradyrhizobium [23] is considered to be the largest group of rhizobia in terms of frequency of isolation [19] and likely to be the ancestor of all rhizobia [24-26], while Rhizobium [27] has the highest number of described species ([28], https://lpsn.dsmz.de/genus/rhizobium; accessed on 19 February 2021). In Sub-Saharan Africa (SSA), the dominance of culturable Bradyrhizobium strains has been repeatedly reported [29,30], including in Côte d'Ivoire [31-33]. However, most of these studies focused on microsymbionts of legume species known to be natural hosts for Bradyrhizobium (e.g., Cajanus cajan, Glycine max, Macroptilium atropurpureum and Vigna unguiculata) [30,32,34]. A pioneering study of soil microbiomes from African savannah woodlands carried out in Mozambique, based on both culture-dependent (isolation directly from soil or from $V$. unguiculata used as trapping host) and culture-independent (HTAS analysis of the 16S rDNA's V3-V4 region from soil DNA) methods, revealed the presence and dominance of the Bradyrhizobium genus with a trapping assay only [35]. Similar results were recently obtained from savannah soils in Botswana [36]. The apparent paucity of the cosmopolitan Bradyrhizobium genus in these recent HTAS analyses and the limited distribution pattern on the African continent of Burkholderia sensu lato (s.l.) from biogeographical surveys [37] raises a number of questions, including the global distribution pattern of the rhizobia population in the Sub-Saharan Africa soils [37]. There are also concerns about the discriminatory power of some variable $(\mathrm{V})$ regions and corresponding primers to accurately estimate the relative abundance of some genera of $\mathrm{N}$-cycling bacteria from environmental samples, as indicated elsewhere [38]. It appears, therefore, that conclusions of the dominance of Bradyrhizobium strains in soils must be treated with caution, and further investigation is required. For example, recent studies suggest the emergence of beta-rhizobia, such as Paraburkholderia species, as potential nodulators of various indigenous legumes, including many species traditionally reported to be preferentially nodulated by Bradyrhizobium (e.g., the South African Acacia karroo and Aspalathus linearis) [39,40].

The identification of rhizobia from soils using the high-throughput amplicon sequencing and phylogeny of the $16 \mathrm{~S}$ rRNA gene was found not sufficient to confirm their ability to nodulate and/or to fix nitrogen [41,42]. However, data on their presence and distribution in soils are valuable for creating a baseline for further studies [8] and may provide new information for land use and crop management decision-making [10,43,44]. Thus, the HTAS of rhizobial communities has been assessed in several ecosystems worldwide, such as temperate arable soils in Poland [45] and coniferous forest soils in North America [41]. However, few HTAS-based studies have been carried out in Africa, and little is known about the global composition and distribution of the rhizobial communities inhabiting soils in African tropical zones, including savannah soils.

In Côte d'Ivoire, the savannah biome covers approximately $54 \%$ of the total area of the country [46]. The vegetation of this region is diversified and varies from woodlands to grasslands and occasional patches of dry scrub in the far north [47]. Narrow gallery forests extend along watercourses and drainage lines. All these vegetation types are traditionally divided into three zones, namely the Sudan savannah in the far north, the Sub- 
Sudan savannah in the north, both of which constitute more than two-thirds of the entire savannah region, and the Guinean savannah. The Guinean savannah, which is located in the southern part of the savannah biome, is sometimes referred to as the transition zone, even though the entire savannah region is transitional between the narrow belt of forest paralleling the coastline and the Sahara [47]. While the Guinean savannah zone has been well studied, including the phylogenetic relationships, ecological niches and functional roles of $N$-cycling bacteria $[48,49]$, the biodiversity and ecology of microorganisms from the two other savannah zones remain relatively unexplored.

The aim of this study was to assess the taxonomy, diversity and distribution of rhizobial genera in soils from the Sudan and the Sub-Sudan tropical savannah zones in Northern Côte d'Ivoire using high-throughput sequencing of the 16S rDNA variable V4-V5 region. In addition, the different $16 S$ rRNA gene variable regions were compared in silico to assess their effectiveness for differentiating all the genera of rhizobia validly published to date.

\section{Materials and Methods}

\subsection{The Study Area}

The study was carried out in the context of the African Soil Microbiome (AfSM) project, and the studied area was located in the savannah zones in Northern Côte d'Ivoire. Côte $\mathrm{d}^{\prime}$ Ivoire is divided roughly into two large agro-ecological regions, of which the northern savannah region, where food crops, cotton and livestock predominate, and the fertile forest zone of the south, where most of the country's cash crops are produced [50]. The boundary that marks the transition from forest to savannah is remarkably irregular (Figure 1a). It is characterized by the presence of an inverted triangular-like structure known as the " V-baoulé » (see [51,52]). Historically, the country was also divided into five zones according to the vegetation types, including (from the far north to the south) the Sudan savannah (I), the Sub-Sudan savannah (II), the Guinean savannah (III), the Semi-deciduous moist forest (IV) and the Evergreen moist forest (V) [46,53,54] (Figure 1b).

The study area covered the Sudanian savannah (I) and the Sub-Sudanian savannah (II) zones (Figure 1c). The annual rainfall is among the lowest in the country [53,55], ranging approximately from 1000 to $1750 \mathrm{~mm}$ per year $[52,53,55]$. The Sub-Sudanian savannah and the Sudanian savannah zones are also characterized by an average annual humidity of $60-70 \%$, annual mean temperature of $24-27^{\circ} \mathrm{C}$ and ferralitic and ferruginous soils $[55,56]$. The vegetation consists of grasslands, wooded grasslands and gallery forests [46,56]. Narrow gallery forests extend along watercourses and drainage basins, where very tall trees, such as Ceiba pentandra, Sterculia tragacantha and Triplochiton scleroxylon, dominate. The dominant tree species of the wooded grasslands are Acacia albida, Khaya senegalensis, Parkia biglobosa, and Tamarindus indica, and herbaceous plants include Andropogon tectorum and Pennisetum purpureum. Dominant trees in savannahs consist also of Butyrospermum parkii, Daniellia oliveri and Lophira lanceolata, as well as Andropogon ivorensis, Loudetia simplex and Panicum phragmitoides for herbaceous species $[53,56]$. As for the cultivated fields, they consist mainly of cashew trees and cereals (maize and rice). The sampled soils belong to the rhizosphere of all the vegetation types we described (Table 1). 

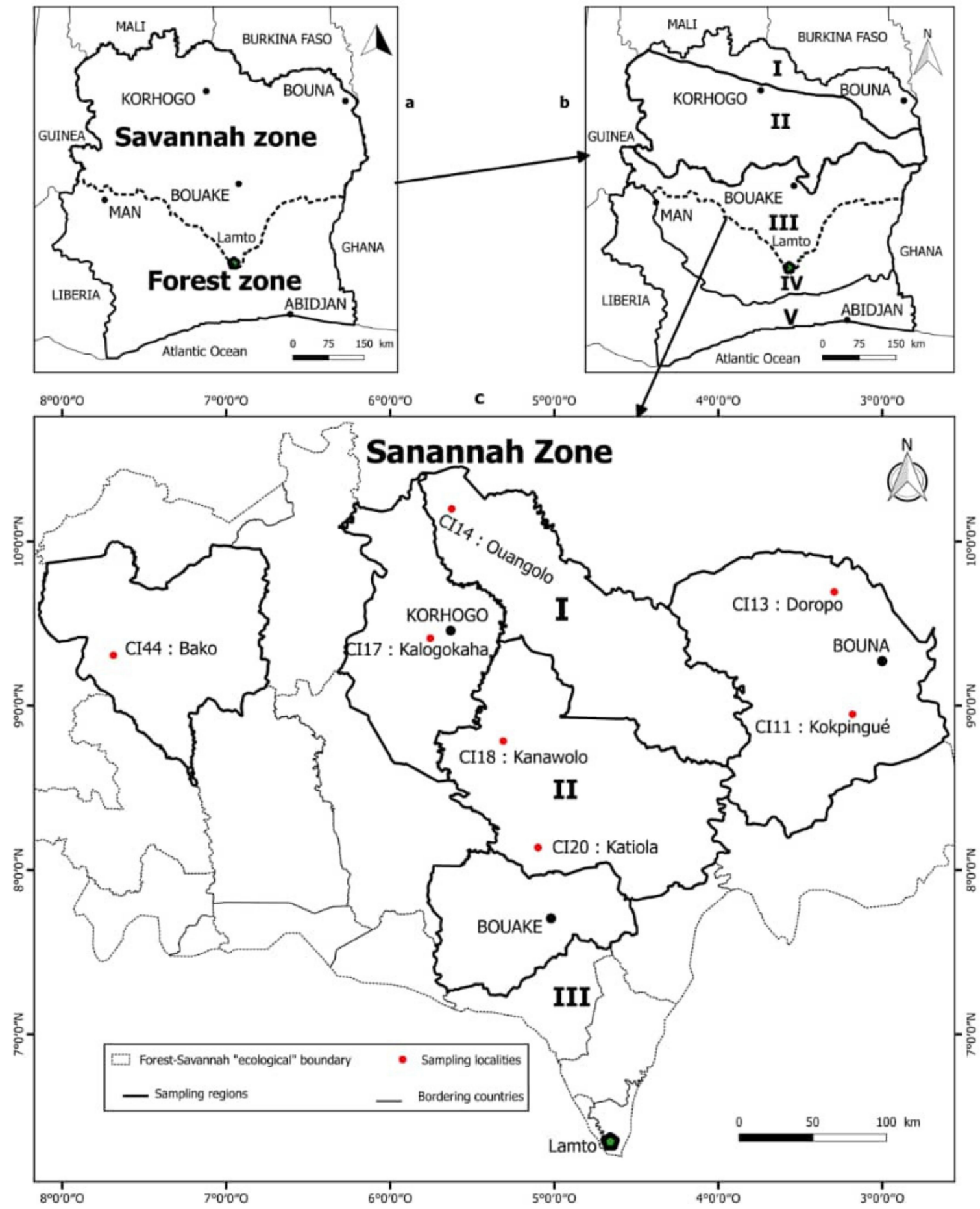

Figure 1. A map of Côte d'Ivoire with (a) the two large agro-ecological regions, i.e., the forest and savannah, both of which are divided (b) into five zones (I, II, III, IV and V) according to the vegetation types. (c) The different localities surveyed in the savannah zones in Northern Côte d'Ivoire are shown with red dots. Lamto is an ecological center for studying the tropical savannah in West Africa (http:/ / lamto.free.fr/; accessed on 4 October 2020). 
Table 1. The geographic positions and main characteristics of the sampled soils.

\begin{tabular}{|c|c|c|c|}
\hline Soil ID & GPS Location & Location (Province/City/Region) & Environment \\
\hline CI11 & N08 $58^{\prime} 52.1^{\prime \prime}, W_{003^{\circ}} 10^{\prime} 50.1^{\prime \prime}$ & Kokpingué/Bouna/Bounkani & Natural wooded grassland soils (Acacia spp.) \\
\hline CI13 & 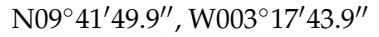 & Doropo/Bouna/Bounkani & Natural wooded grassland soils (Parkia biglobosa) \\
\hline CI14 & $\mathrm{N} 10^{\circ} 04^{\prime} 54.6^{\prime \prime}, \mathrm{W} 005^{\circ} 24^{\prime} 41.0^{\prime \prime}$ & Ouangolo/Ouangolo/Tchologo & Rice field, Native Forest \& natural grassland soils \\
\hline CI17 & 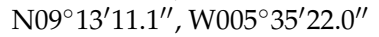 & Kalogokaha/Korhogo/Poro & Cashew field soils \\
\hline CI18 & $\mathrm{N}^{\circ} 8^{\circ} 52^{\prime} 12.5^{\prime \prime}, \mathrm{W} 005^{\circ} 22^{\prime} 08.0^{\prime \prime}$ & Kanawolo/Niakara/Hambol & Cashew field and natural grassland soils (Loudetia spp.) \\
\hline $\mathrm{CI} 20$ & $\mathrm{~N} 08^{\circ} 05^{\prime} 38.2^{\prime \prime}, \mathrm{W} 005^{\circ} 05^{\prime} 01.3^{\prime \prime}$ & Katiola/Katiola/Hambol & Maize \& cassava fields and natural grassland soils \\
\hline CI44 & $\mathrm{N}^{\circ} 9^{\circ} 03^{\prime} 41.5^{\prime \prime}, \mathrm{W} 007^{\circ} 35^{\prime} 20.8^{\prime \prime}$ & Bako/Odienné/Denguélé & Cashew field and woodeed savanna soils \\
\hline
\end{tabular}

\subsection{Soil Sampling}

Soil samples were collected in August-September 2017 from seven sites located in five administrative regions (Table 1) and alongside the national roads. Each sampled soil belongs to the rhizosphere of a natural herbaceous or wooded vegetation and/or a cultivated plant species (cashew, maize, rice etc.) (Table 1). The distance between sampling sites spanned $50-300 \mathrm{~km}$. Each sampling site was represented by an area of approximately $100 \mathrm{~m} \times 50 \mathrm{~m}$ with four independent sample locations (a virtual $1 \mathrm{~m}^{2}$ quadrat) at the corners of the oblong (Figure S1). At each of the four independent sample locations, four topsoil cores ( $2 \mathrm{~cm}$ in diameter and $5 \mathrm{~cm}$ in depth) (pseudo-replicate samples) were collected, pooled together, and homogenized into a composite sample of approximately $25 \mathrm{~g}$ (replicate sample). Four independent replicate samples $(4 \times 25 \mathrm{~g})$ obtained from four sample locations at each sampling site were kept in a labelled sterile plastic bag and formed an independent soil sample. This process was repeated for all seven sampling sites. In total, seven independent soil samples were obtained. Each soil sample taken from the two savannah zones from northern Côte d'Ivoire (CI) is referred to by the soil numbers $11,13,14,17,18,20$ or 44 (Table 1). After sampling, the soil samples were transported to the laboratory, where they were stored at $4^{\circ} \mathrm{C}$ prior to a shipment to South Africa for further analysis.

\subsection{Analysis of Soil Physicochemical Properties}

The analysis of soil physico-chemical characteristics was carried out by Bemlab (Strand, Cape Province, South Africa) using standard methods. Briefly, prior to analyses, the samples were air-dried at room temperature for four days, separated from roots and debris, and passed through a $2 \mathrm{~mm}$ sieve. The sieved replicate samples of each sampling site were subsequently pooled together to obtain a composite soil sample. Physical characteristics (fractions of clay, sand and silt) were analyzed using the Bouyoucos sedimentation method (hydrometer method) [57]. The classification of soils according to texture was based on the standard USDA particle-size classification using the Soil Texture online Calculator (https: //www.nrcs.usda.gov/wps/portal/nrcs/detail/soils/survey/?cid=nrcs142p2_054167; accessed on 8 April 2021). The $\mathrm{pH}$ (aqueous) was measured as described [58], while the oxidizable carbon content was determined using the dichromate oxidation method (the Walkley-Black method) [59]. Soil chemical parameters (exchangeable and soluble $\mathrm{Na}, \mathrm{K}$, $\mathrm{Ca}, \mathrm{Mg}, \mathrm{Al}, \mathrm{Fe}, \mathrm{Mn}$ and $\mathrm{P}$ ) were analyzed using the Mehlich No. 3 soil test extractant with Inductively Coupled Atomic Emission Spectrometry (ICP-AES) procedures [60].

\subsection{DNA Extraction, PCR, MiSeq Sequencing, and Sequence Data Analysis}

Genomic DNA (gDNA) extraction, amplification and high-throughput amplicon sequencing were carried out as in Nkuekam et al. [61], with few modifications. DNA extraction was conducted at the Centre for Microbial Ecology and Genomics (University of Pretoria, South Africa). Briefly, soil samples were first ground with Powerlyser (Mo Bio Laboratories Inc.), and the genomic DNA was extracted from $0.25 \mathrm{~g}$ of soil using the PowerSoil DNA isolation kit (Mo Bio Laboratories Inc., Carlsbad, CA, USA). The success of the extraction was verified by $1 \%$ agarose gel electrophoresis visualizing under UV light. DNA amplification was conducted at the MRDNA sequencing facility (www. mrdnalab.com, accessed on 25 June 2021, Shallowater, TX, USA) in a 30-cycle PCR using the 
HotStarTaq Plus Master Mix Kit (Qiagen, Germantown, MD, USA) [61]. The V4-V5 variable region of the $16 \mathrm{~S}$ rRNA gene was amplified and sequenced using the alternative forward primer 515F-Y (5'-GTGYCAGCMGCCGCGGTAA-3'; [62] $)$ and the universal reverse primer 909-928 (5'-CCCCGYCAATTCMTTTRAGT-3'; [63]), with 12 nucleotides unique barcode at 5-end of 515F-Y for each soil sample. High-throughput amplicon sequencing was performed using an Illumina MiSeq platform at the MRDNA sequencing facility.

For the processing of the sequencing data, raw sequences were first checked for reads quality using FastQC (https:/ / www.bioinformatics.babraham.ac.uk/projects/fastqc/; accessed on 1 May 2021). Reads were then sorted based on unique soil sample tags using Sabre 1.0 program (https://github.com/najoshi/sabre; accessed on 1 May 2021) with default parameters and trimmed for primer and barcode removal using cutadapt 2.10 [64] The trimmed sequences were subsequently denoised using the DADA2 algorithm [65] that resolves Illumina-sequenced amplicon errors to generate amplicon sequence variants (ASVs). ASVs were classified using the RDP classifier [66] with default parameters. The assignment of ASVs to rhizobia taxa was processed through a search for similar sequences conducted with BLAST v. 2.9.0+ [67] against the SILVA 138.1 database [68].

The taxonomic affiliations obtained with SILVA was manually validated at the genus level using several approaches, including (i) BlastN with NCBI/GenBank online standard databases (nucleotide collection (nr/nt) and Whole-genome shotgun contigs (wgs)) to select closely related reference sequences, (ii) phylogenetic reconstructions and (iii) similarity level calculations between the ASVs and selected rhizobial reference sequences. Briefly, V4-V5 edited sequences were aligned with MUSCLE as implemented in MEGA software v. 7 and phylogenies were inferred subsequently with evolutionary trees reconstructed using the maximum likelihood (ML) and neighbor-joining (NJ) methods [69,70]. Bestfit nucleotide substitution models were selected according to the Bayesian information criterion (BIC) [71] and the uncorrected genetic distances calculated as in Rashid et al. [72] Phylogenetic analyses also included 16S rRNA gene sequences derived from archived genome data of the type species of all the 18 alphaproteobacterial and betaproteobacterial genera harboring rhizobia isolates [15], except for Paraburkholderia. P. graminis PHS1 16S rRNA gene data was used in the analysis as a surrogate of P. graminis type strain C4D1M, for which no full rRNA gene sequence was accessible at the time of writing (June 2021). Details of the type species of all the 18 bacterial genera harboring rhizobia are listed in Table 2. 
Table 2. A list of the 18 alpha-and beta-proteobacterial genera harboring rhizobia, their type species used in this study and their corresponding relevant characteristics.

\begin{tabular}{|c|c|c|c|c|c|c|c|}
\hline No. & Genus & $\begin{array}{l}\text { Number of } \\
\text { Species }^{3}\end{array}$ & $\begin{array}{l}\text { Number of Nod }+ \text { I } \\
\text { Fix }+ \text { species }{ }^{4}\end{array}$ & Genus Type Species & Genome Accession & $\begin{array}{l}\text { 16S rRNA Gene Full } \\
\text { Size (bp) }{ }^{6}\end{array}$ & $\begin{array}{c}\text { Symbiotic Capacity of the Genus Type } \\
\text { Species }\end{array}$ \\
\hline 1 & Allorhizobium & 8 & 1 & Allorhizobium undicola ORS $992^{\mathrm{T}}$ & NZ_JHXQ01000045 & 1482 & Nod+/Fix+ [73] \\
\hline 2 & Aminobacter & 7 & 1 & Aminobacter aminovorans DSM $7048^{\mathrm{T}}$ & NZ_SLZO01000023 & 1484 & unknown [74] \\
\hline 3 & Azorhizobium & 3 & 2 & Azorhizobium caulinodans ORS $571^{\mathrm{T}}$ & AP009384 & 1482 & $\mathrm{Nod}+/ \mathrm{Fix}+[75]$ \\
\hline 4 & Bradyrhizobium & 57 & 55 & Bradyrhizobium japonicum USDA $6^{\mathrm{T}}$ & NC_017249 & 1488 & Nod+/Fix+ [23] \\
\hline 5 & Cupriavidus $^{1}$ & 18 & 2 & Cupriavidus necator $\mathrm{N}-\mathrm{1}^{\mathrm{T}}$ & CNE_1c16970 & 1531 & Nod $-{ }^{7}[76]$ \\
\hline 6 & Devosia & 26 & 1 & Devosia riboflavina $\mathrm{IFO} 13584^{\mathrm{T}}$ & NZ_JQGC01000043 & 1481 & nod/fix genes were not detected [77] \\
\hline 7 & Ensifer & 20 & 16 & Ensifer adhaerens Casida $\mathrm{A}^{\mathrm{T}}$ & NZ_CP015880 & 1484 & Nod-, nod genes were not detected [78] \\
\hline 8 & Mesorhizobium & 56 & 45 & Mesorhizobium loti DSM $2626^{\mathrm{T}}$ & NZ_QGGH01000001 & 1484 & Nod+/Fix+ $[79,80]$ \\
\hline 10 & Microvirga & 17 & 5 & Microvirga subterranea DSM $14364^{\mathrm{T}}$ & NZ_QQBB01000028 & 1486 & unknown [82] \\
\hline 11 & Neorhizobium & 4 & 4 & Neorhizobium galegae HAMBI $540^{\mathrm{T}}$ & HG938353 & 1480 & Nod $+/$ Fix $+[83,84]$ \\
\hline 12 & Ochrobactrum $^{2}$ & 17 & 2 & Ochrobactrum anthropi ATCC $49188^{\mathrm{T}}$ & NC_009667 & 1482 & non-symbiotic bacterium $[85,86]$ \\
\hline 13 & Paraburkholderia $^{1}$ & 73 & 16 & Paraburkholderia graminis PHS1 ${ }^{5}$ & GCF_003330785 & 1532 & unknown $[87,88]$ \\
\hline 14 & Pararhizobium & 6 & 2 & Pararhizobium giardinii $\mathrm{H} 152^{\mathrm{T}}$ & NZ_KB902704 & 1484 & Nod+/Fix+ $[89,90]$ \\
\hline 15 & Phyllobacterium & 12 & 3 & Phyllobacterium myrsinacearum DSM $5892^{\mathrm{T}}$ & NZ_SHLH01000013 & 1484 & Nod- $[91]$ \\
\hline 16 & Rhizobium & 91 & 48 & Rhizobium leguminosarum USDA $2370^{\mathrm{T}}$ & GCA_003058385 & 1480 & Nod+/Fix+ [27] \\
\hline 17 & Shinella & 8 & 1 & Shinella granuli DSM $18401^{\mathrm{T}}$ & NZ_SLVX01000061 & 1484 & unknown [92] \\
\hline 18 & Trinickia $^{1}$ & 7 & 1 & Trinickia symbiotica JPY- $345^{\mathrm{T}}$ & NZ_PTIR01000049 & 1530 & Nod+/Fix+ [76] \\
\hline
\end{tabular}

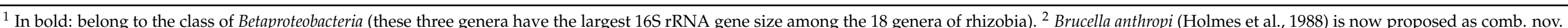

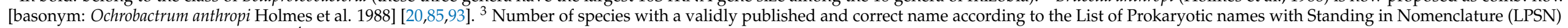

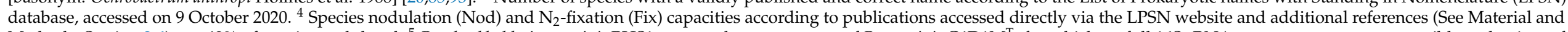

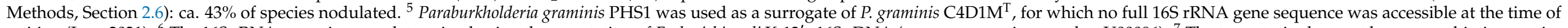

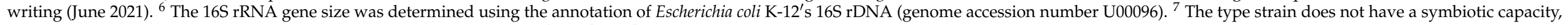
but many strains belonging to the same species were reported as Nod+/Fix+ [76,94]. 


\subsection{Statistical and Diversity Index Analyses}

The statistical and diversity index analyses were performed using R v. 4.0.3 [95], including the R packages vegan [96], phyloseq [97] and ggplot2 [98]. The rarefaction curves were computed using the vegan function rarefy, which is based on Hurlbert's formula [99] to evaluate the sequencing efforts provided. As a normalization step to reduce bias associated with different sequencing depths, all samples were subsampled down to the size of the smallest sample. Each sample was rarefied to 1384 reads. Indices of richness (Chao1) and alpha diversity (Shannon, Simpson and Fisher) were calculated by savannah zone, and a non-parametric Wilcoxon test was used to compare the mean values at the significance level of $5 \%$. The degree of community differentiation (beta-diversity) was evaluated to calculate Jaccard's similarity coefficient and the Bray-Curtis index of (dis)similarity for each ASV. The relationship between the ASVs of rhizobia and the environmental parameters that characterize the soils of the savannah zones of Northern Côte d'Ivoire was assessed by canonical correspondence analysis (CCA) using ten physico-chemical parameters. Prior to drawing the relative abundance of rhizobia taxon per soil sample, the sample counts of ASVs were used to calculate relative abundance by computing the ratio of the count of each sample by the sum of the counts of all samples. The obtained relative abundance of counts was used to draw the bar plot of relative abundance of ASVs by genera and family between samples. The heatmap was created using the ecologically organized plot_heatmap function of the phyloseq package, which is a variant of the heatmap provided by the NeatMap package [100]. To draw the heatmap, we used the NMDS ordination method and the Bray-Curtis distance. The $16 \mathrm{~S}$ rRNA gene sequences used in this study are available in the NCBI SRA database under accession number SRR13623326 (CI11), SRR13623324 (CI13), SRR13623323 (CI14), SRR13623320 (CI17), SRR13623319 (CI18), SRR13623317 (CI20) and SRR13623335 (CI44).

\subsection{In Silico Evaluation of the $16 S$ rRNA Gene V-Regions Discriminatory Power for Rhizobia}

The aim of this analysis was to compare in silico the discriminatory power at the genus level of nine commonly used 16S rRNA gene V-regions for rhizobia. Prior to this analysis, we estimated the current number of species of rhizobia. We counted the number of species of rhizobia validly published within the 18 alphaproteobacterial and betaproteobacterial genera harboring rhizobial species and provided on the List of Prokaryotic names with Standing in Nomenclature (LPSN), also known as bacterio.net [101]. We also documented the prevalence of species with nodulation (Nod) and/or $\mathrm{N}_{2}$-fixation (Fix) capacities using the original publications describing novel taxa of rhizobia and accessible on the LPSN website, as well as the more recent publications that reviewed the symbiotic features of rhizobial taxa [102-104]. All the data are reported in Table 2. As for the evaluation of the discriminatory power of V-regions, nine V-regions (V1 to V9) spanning the entire 16S rRNA gene and commonly targeted in microbial metagenomic analyses were selected [63,105-107] (Table 3). The corresponding universal primers targeting the selected V-regions and their relevant characteristics are reported in Table 3. The V-regions were compared to the fulllength size of the 16S rRNA gene sequences with a method used in VanInsberghe et al. [108]. Briefly, the full-length 16S rRNA gene sequences were aligned for all the 18 genera with MAFFT version 7 using the Q-INS-I method [109] and followed by a maximum likelihood phylogenetic tree reconstruction as well as by a pairwise similarity distances calculation as in Rashid et al. [72]. Similarity values were used to identify the uniquely distinguishable taxa at $97 \%, 99 \%$ or $100 \%$ cut-offs. Subsequently, the full-length $16 \mathrm{~S}$ rRNA gene sequence alignment was edited to the total number of positions that corresponds to those of each V-region, in addition to that of the V1-V9 region, which is the near-full-length size of the $16 \mathrm{~S}$ rRNA gene (Table 3). The total number of positions in each edited dataset was used to calculate the similarity values that served to identify the uniquely distinguishable taxa for the given V-region. 
Table 3. Nine commonly used $16 \mathrm{~S}$ rDNA primers targeting the variable regions and the V1-V9 region and corresponding relevant characteristics used in this study.

\begin{tabular}{|c|c|c|c|c|c|c|c|}
\hline $\begin{array}{l}\text { 16S rDNA } \\
\text { V-region }^{1}\end{array}$ & $\begin{array}{c}\text { Forward } \\
\text { Name }^{2}\end{array}$ & Forward Sequence $\left(5^{\prime}\right.$ to $\left.3^{\prime}\right)$ & Reverse Name & Reverse Sequence (5' to $\left.3^{\prime}\right)$ & $\begin{array}{l}\text { Size (bp) Variation } \\
\text { Among Rhizobia }^{3}\end{array}$ & $\begin{array}{c}\text { Size variation } \\
\text { OnceEdited (Primers } \\
\text { Deleted) }\end{array}$ & $\begin{array}{l}\text { Total Positions in the } \\
\text { Final Dataset Aligned }\end{array}$ \\
\hline V1-V9 & $27 \mathrm{~F}$ & AGAGTTTGATCMTGGCTCAG & 1492Rmod & TACGGYTACCTTGTTAYGACTT & 1445-1497 & $1403-1455$ & 1486 \\
\hline V1-V2 & $27 \mathrm{~F}$ & AGAGTTTGATCMTGGCTCAG & $337 \mathrm{R}$ & CYIACTGCTGCCTCCCGTAG & $320-350$ & $280-310$ & 325 \\
\hline V1-V3 & $27 \mathrm{~F}$ & AGAGTTTGATCMTGGCTCAG & $534 \mathrm{R}$ & ATTACCGCGGCTGCTGG & $468-523$ & $431-486$ & 501 \\
\hline V3-V4 & $341 \mathrm{~F}$ & CCTACGGGNGGCWGCAG & $805 \mathrm{R}$ & GACTACHVGGGTATCTAATCC & $440-465$ & $402-427$ & 427 \\
\hline V3-V5 & $341 \mathrm{~F}$ & CCTACGGGNGGCWGCAG & $926 \mathrm{Rb}$ & CCGTCAATTYMTTTRAGT & $560-585$ & $525-550$ & 550 \\
\hline V4 & $515 \mathrm{~F}$ & GTGCCAGCMGCCGCGGTAA & $806 \mathrm{R}$ & GGACTACHVGGGTWTCTAAT & 292 & 253 & 253 \\
\hline V4-V5 & $515 \mathrm{~F}-\mathrm{Y}$ & GTGYCAGCMGCCGCGGTAA & 909-928R & CCCCGYCAATTCMTTTRAGT & 413 & 374 & 374 \\
\hline V5-V7 & $799 \mathrm{~F}$ & AACMGGATTAGATACCCKG & $1193 R$ & ACGTCATCCССАССТTCC & $409-417$ & $372-380$ & 385 \\
\hline V6-V9 & $928 \mathrm{~F}$ & TAAAACTYAAAKGAATTGACGGGG & 1492Rmod & TACGGYTACCTTGTTAYGACTT & $605-612$ & $560-567$ & 576 \\
\hline V7-V9 & $1100 \mathrm{~F}$ & YAACGAGCGCAACCC & 1492Rmod & TACGGYTACCTTGTTAYGACTT & $408-415$ & $371-378$ & 380 \\
\hline
\end{tabular}

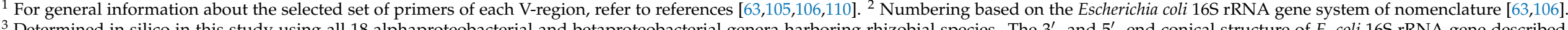

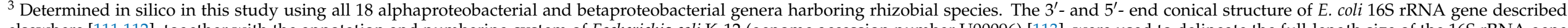

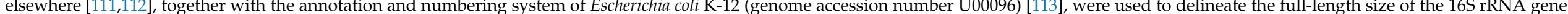
sequence. ${ }^{4}$ Obtained with the $16 \mathrm{~S}$ rRNA gene sequences (without primers sequences) of all the 18 genera of rhizobia aligned using Muscle as implemented in MEGA7. 


\section{Results}

We carried out a high-throughput amplicon sequencing (HTAS) analysis of the 16S rRNA gene V4-V5 region to assess the taxonomy, diversity and distribution of rhizobial taxa in seven soils in the Sudan savannah (I) and the Sub-Sudan savannah (II) zones in Northern Côte d'Ivoire (Figure 1). These two zones have been largely neglected in terms of fundamental research in microbial ecology, and this study provides their first comprehensive rhizobial microbiome analysis. The sampled soils from the two zones were analyzed for their physico-chemical properties prior to the HTAS analysis.

\subsection{Physico-Chemical Properties of Soil Samples}

The soils' physico-chemical data are reported in Supplementary Table S1. The seven studied localities have similar soil textures characterized by a high proportion of sand $(>70 \%)$ but can be divided into two subgroups: soils CI13, CI14, CI17, CI18 and CI20 were sandy loams, while CI11 and CI44 were loamy sand. The $\mathrm{pH}$ of the seven soils ranged from 5 to 7 , being consistent with the soil $\mathrm{pH}$ range expected in tropical humid regions (https:/ / www.qld.gov.au/environment/land/management/soil/soil-properties/ ph-levels; accessed on 8 April 2021). Soils CI11 and CI13, both of which were from the locality of Bouna in the north-east (Figure 1), were neutral ( $\mathrm{pH}$ 6.6), while CI14, CI17, CI18, $\mathrm{CI} 20$ and CI44 soils were acidic $(\mathrm{pH}<6.5)$. CI14 $(\mathrm{pH}=6.4)$ was the least acidic soil (nearly neutral). The distribution of the soil samples according to the chemical properties was more heterogeneous. CI11 was among the soil samples having the highest values of calcium $\left(\mathrm{Ca}^{2+}\right)$, magnesium $\left(\mathrm{Mg}^{2+}\right)$, potassium $\left(\mathrm{K}^{+}\right)$and sodium $\left(\mathrm{Na}^{+}\right)$, while CI44 and CI-17 had the lowest values for the same mineral elements.

\subsection{Sequence Data and Taxonomic Affiliation}

The amplification of the total DNA extracted from the seven soil samples using V4-V5 primers yielded ca. 400-500 nucleotide length products, as expected for bacteria (Table 3). The rarefaction curves reach the asymptote with less than 1000 sequences, suggesting that the sequencing effort of each amplicon was sufficient (Figure S2). From a total of 900,760 sequences obtained through Illumina's high throughput sequencing platform, a total of 786,283 sequences were considered for the clustering after sequence trimming. When clustered and quality-controlled, the 786,283 sequences yielded 5997 ASVs in total, of which 80 (less than $2 \%$ ) matched to rhizobia in the SILVA database. This assignment of the ASVs to rhizobia taxa was further refined using a multi-step approach that includes phylogenetic analyses of the ASVs (Figures 2 and S3) as well as a genetic distance comparison (Table S2) and online blastN analyses. Phylogenetic assignments of the ASVs performed with a subset of 86 closely related sequences (99 to 100\% similar) and/or 18 type species of Proteobacteria harboring rhizobia species validly published to date yielded similar taxonomic affiliations (see Figures 2 and S3, respectively). Together, these different analyses improved the taxonomic identification, with 77 ASVs (equivalent to 15,886 sequences) being confirmed as rhizobia (Figure 2; Tables S3 and S4). The 77 ASVs belonged to 12 genera of rhizobia (Bradyrhizobium, Cupriavidus, Devosia, Ensifer, Mesorhizobium, Methylobacterium, Microvirga, Neorhizobium, Paraburkholderia, Rhizobium, Shinella and Trinickia) (Figure 2) and were present in six families (Burkholderiaceae, Devosiaceae, Methylobacteriaceae, Nitrobacteraceae, Phyllobacteriaceae and Rhizobiaceae) of the classes Alphaproteobacteria (09 genera) and Betaproteobacteria (03 genera) (Table S3). In silico taxonomic assignments of the 77 ASVs revealed that many families in the class Alphaproteobacteria such as Bradyrhizobiaceae (renamed Nitrobacteraceae), Methylobacteriaceae or Phyllobacteriaceae are not accurately assigned in SILVA 138 database, as reported elsewhere [114]. Indeed, these three families were misidentified, including Xanthobacteraceae, Beijerinckiaceae and Rhizobiaceae, respectively (Table S2). These weaknesses were compensated using the validly published names reported on the LPSN website [101]. 


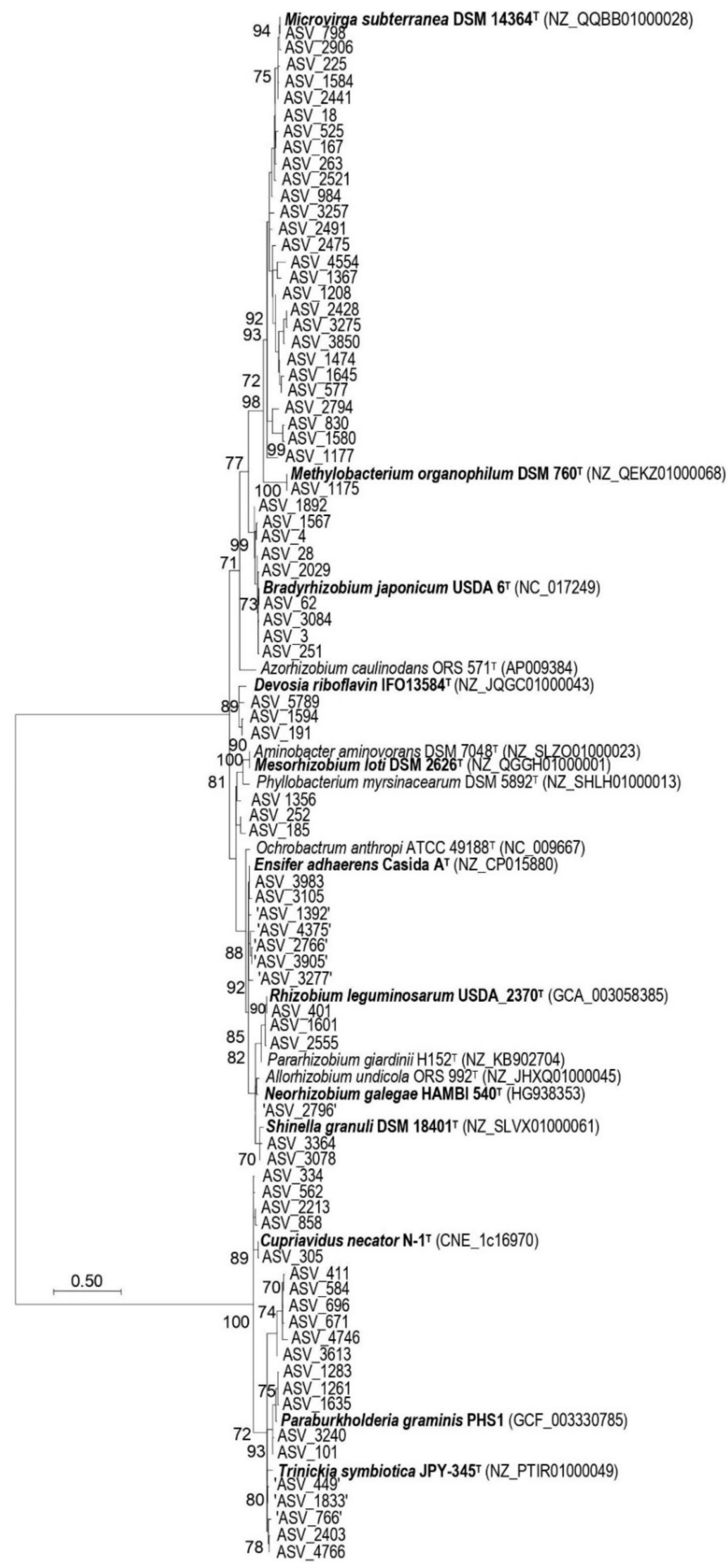

Figure 2. An unrooted phylogenetic tree of ASVs of rhizobia detected in savannah soils of Northern Côte d'Ivoire using the $16 \mathrm{~S}$ rDNA V4-V5 variable region with all the type species of 18 Alpha- and 
Beta-proteobacteria genera harboring described rhizobia species. Evolutionary relationships were inferred using the Maximum Likelihood method based on the Tamura 3-parameter using a discrete Gamma distribution with invariant sites $(\mathrm{T} 92+\mathrm{G}+\mathrm{I})$. Bootstrap values $\geq 70 \%$ based on 1000 replicates are indicated, and the scale bar represents the number of substitutions per site. Type species of the 18 genera are displayed with strain ID followed by the GenBank 16S rRNA gene accession number. DNA sequences for ASVs used in this tree are provided in Table S3, and they are taken from the complete sequencing data archived in the NCBI SRA database. All ASVs that could not be accurately identified in the tree are enclosed in quotation marks.

Of the 12 genera detected, Microvirga (24 ASVs), Paraburkholderia (11 ASVs) and Bradyrhizobium (9 ASVs) are the most dominant, following the criteria of the number of ASVs detected per genus (Table S5). These three genera represented more than $57 \%$ of the total rhizobial ASVs (Table S5). Of the 18 Alpha- and Beta-proteobacterial genera harboring described rhizobial species, those not detected in this analysis included Allorhizobium, Aminobacter, Azorhizobium, Ochrobactrum, Pararhizobium and Phyllobacterium. Interestingly, these six genera have a low relative number of validly published species (only $11 \%$ ) (Table 2).

\subsection{Relative Abundance of Rhizobia Taxa per Soil Sample}

Relative abundance was expressed as a percentage with respect to the total number of sequences in each soil sample. The analysis of relative abundance showed that Nitrobacteraceae (formerly Bradyrhizobiaceae) was by far the most abundant taxon (Figure 3).

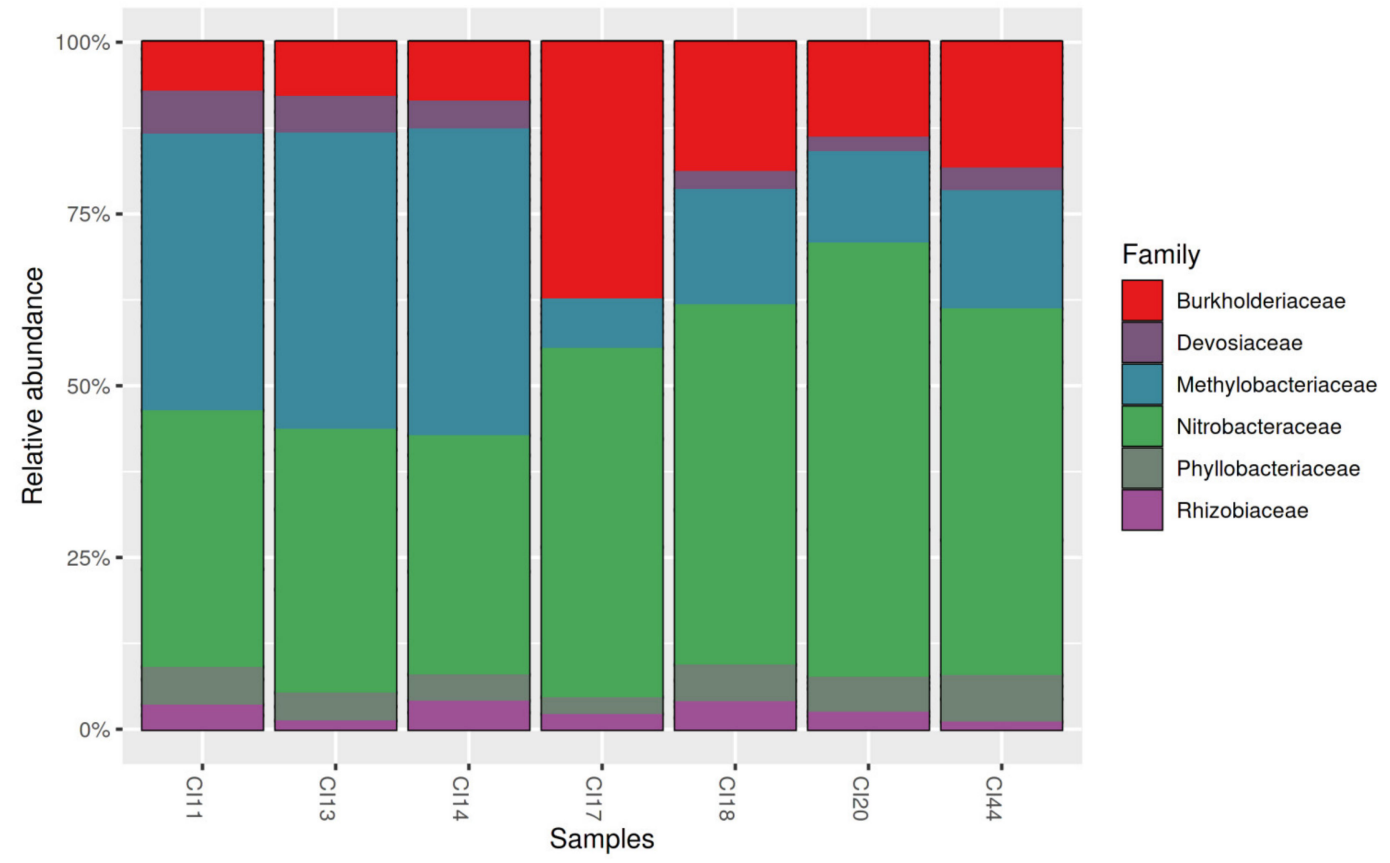

Figure 3. The relative abundance of the six families of rhizobia in northern Côte d'Ivoire savannah soils. CI11: soil from the locality of Kokpingué; CI13: Doropo; CI14: Ouangolo; CI17: Kalogokaha; CI18: Kanawolo; CI20: Katiola; CI44: Bako.

At the genus level, Bradyrhizobium (Nitrobacteraceae), Microvirga (Methylobacteriaceae) and Paraburkholderia (Burkholderiaceae) were the most abundant taxa (Figure 4), where the cumulative relative abundance of these three genera across all soil samples represented ca. $80 \%$ of all sequences, as follow: Bradyrhizobium (49.1\%), Microvirga (21.4\%) and Parabukholderia (9.0\%) (Table S5). The two least prevalent genera were Neorhizobium $(0.19 \%)$ and Shinella $(0.31 \%)$, being detected in only one and two soils, respectively (Figure 4; Table S5). 


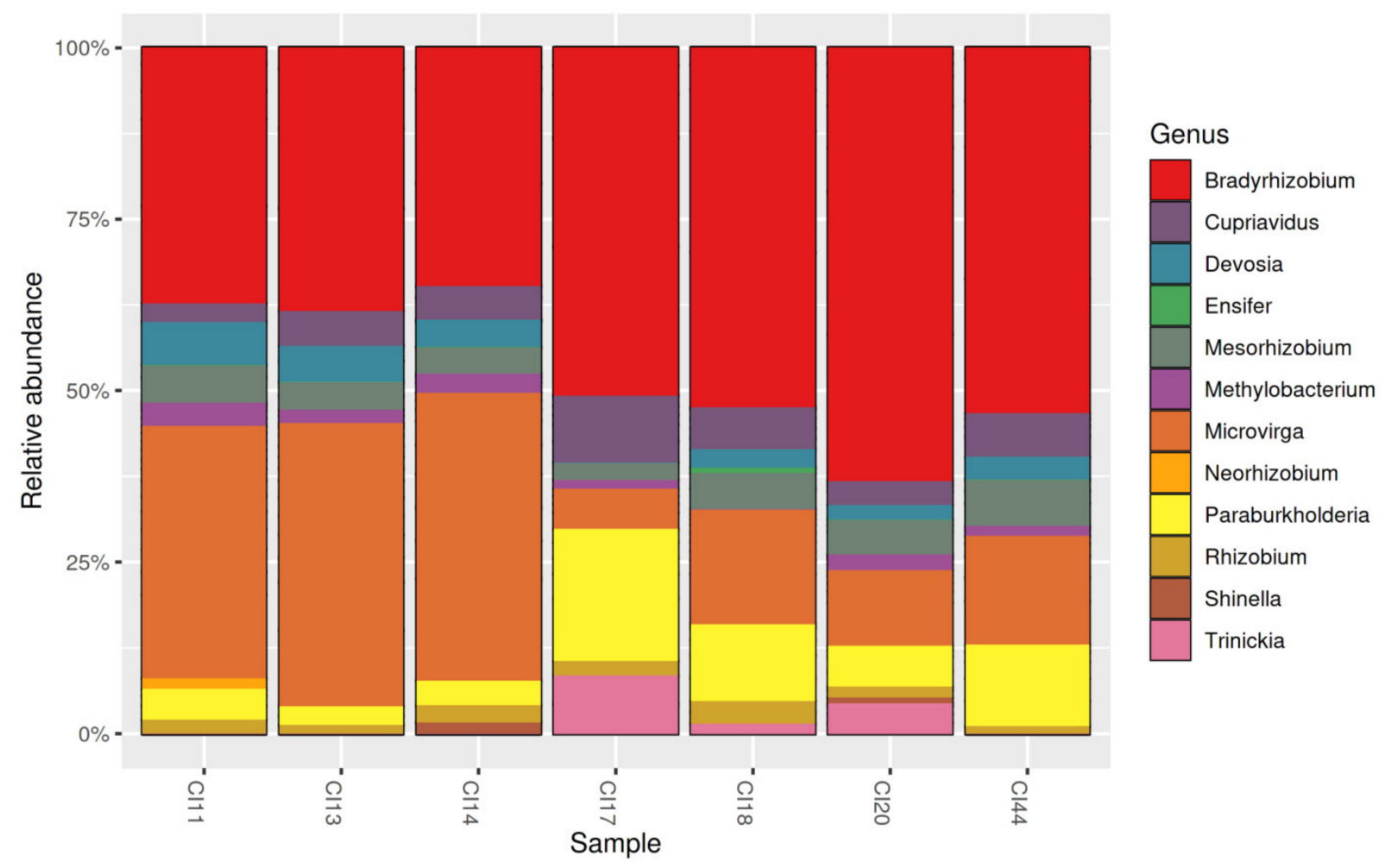

Figure 4. The relative abundance of the 12 genera of rhizobia detected from the savannah soils in Northern Côte d'Ivoire. CI11: soil from the locality of Kokpingué; CI13: Doropo; CI14: Ouangolo; CI17: Kalogokaha; CI18: Kanawolo; CI20: Ka-tiola; CI44: Bako.

Of the 77 ASVs, two were highly abundant (>10\%); namely ASV_3 (17. 8\%) and ASV_4 (17. 7\%) (Table S3). ASV_3, ASV_4, ASV_28 and ASV_62, all of which belonged to the genus Bradyrhizobium genus, were prevalent in all soil samples (Figure 5). Six of the 12 rhizobial genera detected in this study were ubiquitous in the savannah soils of Northern Côte d'Ivoire. They included Bradyrhizobium, Cupriavidus, Mesorhizobium, Microvirga, Paraburkholderia and Rhizobium (Figure 4; Table S5).

\subsection{Richness and Diversity Indices}

The seven soils had a comparable number of ASVs (ASVs richness) which ranged from 24 (soil \# CI11 and \# CI17) to 35 (\# CI20) (Table S5). The indices of richness (Chao1) and alpha diversity (Shannon, Simpson and Fisher) analyzed per savannah biome are similar among the Sudanian savannah and the Sub-Sudanian savannah (Table S6). The community diversity indices showed that the sites CI18 and CI44 shared the lowest value of Bray-Curtis dissimilarity (calculated value of 0.29), meaning that these two sites shared the highest number of ASVs together when the composition of all the seven sites was compared. In contrast, CI14 and CI17 had the lowest number of shared ASVs (Table 4). 


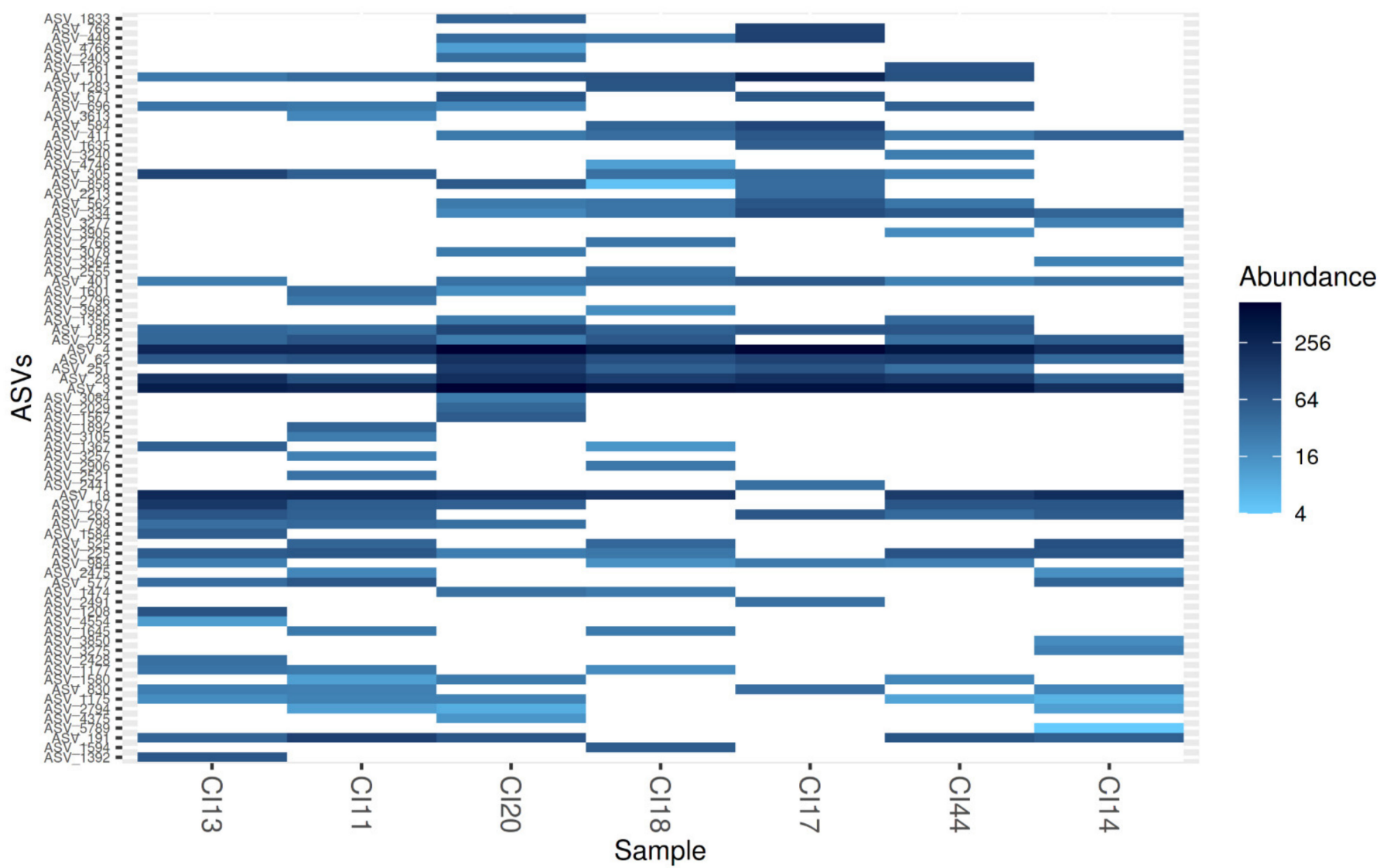

Figure 5. A heat map illustrating the relative abundance and the ubiquity of each of the 77 ASVs detected from the savannah soils in Northern Côte d'Ivoire.

Table 4. The measure of the beta-diversity as indicated by the Bray-Curtis distance.

\begin{tabular}{ccccccc}
\hline Bray-Curtis Distance & CI11 & CI13 & CI14 & CI17 & CI18 & CI20 \\
\hline CI13 & 0.30 & - & - & - & - & - \\
CI14 & 0.33 & 0.40 & - & - & - & - \\
CI17 & 0.65 & 0.58 & 0.67 & - & - & - \\
CI18 & 0.46 & 0.46 & 0.51 & 0.41 & - & - \\
CI20 & 0.52 & 0.49 & 0.58 & 0.39 & 0.38 & - \\
CI44 & 0.40 & 0.37 & 0.43 & 0.41 & 0.29 & 0.34 \\
\hline
\end{tabular}

The Jaccard distance from the community diversity analysis revealed that the sites CI11 and CI17 were the most dissimilar (Jaccard distance of 0.82) while CI44 and CI20 were the least dissimilar among all the seven sites (Jaccard distance of 0.52) (Table 5).

Table 5. The measure of the beta-diversity as indicated by the Jaccard distance.

\begin{tabular}{ccccccc}
\hline Jaccard Distance & CI11 & CI13 & CI14 & CI17 & CI18 & CI20 \\
\hline CI13 & 0.53 & - & - & - & - & - \\
CI14 & 0.61 & 0.64 & - & - & - & - \\
CI17 & 0.82 & 0.74 & 0.79 & - & - & - \\
CI18 & 0.75 & 0.70 & 0.77 & 0.61 & - & - \\
CI20 & 0.67 & 0.69 & 0.70 & 0.70 & 0.67 & - \\
CI44 & 0.62 & 0.54 & 0.63 & 0.63 & 0.62 & 0.52 \\
\hline
\end{tabular}


The canonical correspondence analysis showed that the $\mathrm{pH}, \mathrm{C}, \mathrm{Ca}^{2+}, \mathrm{K}^{+}, \mathrm{Mg}^{2+}$ and $\mathrm{Na}^{+}$were the soil properties that most strongly influenced the distribution of rhizobial taxa from the savannah soils in Northern Côte d'Ivoire (Figure 6).

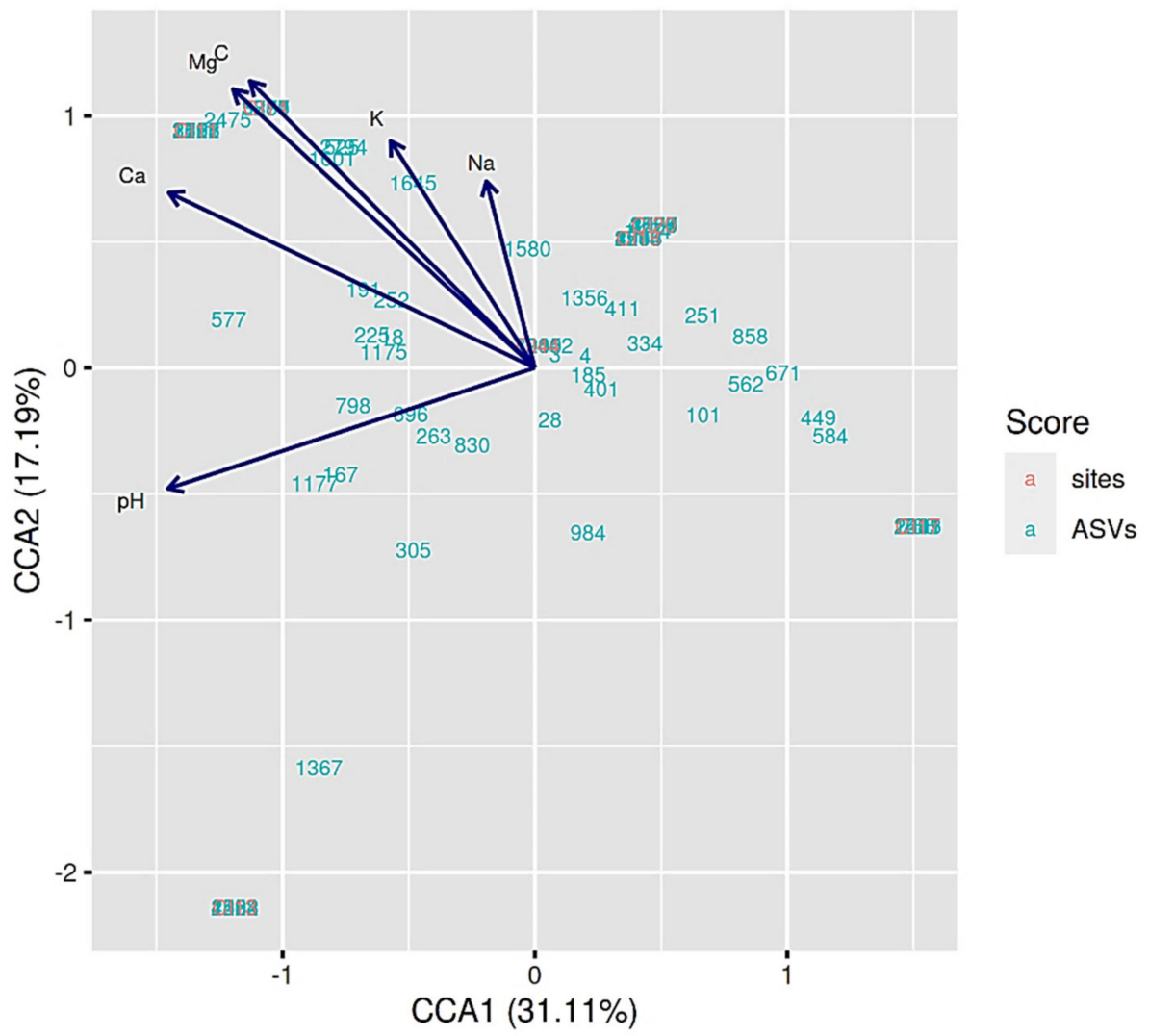

Figure 6. Canonical correspondence analysis (CCA) showing the relationship between the $77 \mathrm{ASV}$ of rhizobia (represented by their number) and the physico-chemical parameters of soils from Northern Côte d'Ivoire. The arrows represent soil properties.

\subsection{In Silico Evaluation of $16 S$ rDNA V-Regions Discriminatory Power for Rhizobia}

In an attempt to assign the 77 rhizobial ASVs detected from the savannah soils in Northern Côte d'Ivoire to the 18 genera of rhizobia validly published to date, we found that some genera type species, including Aminobacter aminovorans DSM $7048^{\mathrm{T}}$ and Mesorhizobium loti DSM $2626^{\mathrm{T}}$, had identical $16 \mathrm{~S}$ rRNA gene V4-V5 region (Figure 2). Thus, we struggled to cluster at the genus level all the ASVs that belong to the Aminobacter-Mesorhizobium clade, including ASV_185, ASV_252 and ASV_1356. These weaknesses were compensated using several approaches, including BlastN with NCBI/GenBanK online nr/nt and wgs databases. However, the taxonomic affiliation of nine ASVs that belonged to the clades of AllorhizobiumNeorhizobium-Pararhizobium-Rhizobium and Burkholderia-Caballeronia-Parabukholderia was partially solved (Figure 2, Table S2). In silico comparisons of different 16S rRNA gene variable regions to assess their effectiveness for differentiating rhizobia confirmed that the V4-V5 region has an insufficient resolution for separation of all genera of rhizobia at the genus level. As expected [115], the V4 region alone did also not perform well, regardless of the threshold used for the delineation. Both V4 and V4-V5 primer pairs were the only sets of primers that could not discriminate all 18 genera at the ASV level (one nucleotide polymorphism level). In contrast, the analysis showed that the V5-V7 region was the best target for genus discrimination (Figure 7): the V5-V7 region discriminated all the 18 genera of rhizobia at $100 \%$ and $99 \%$ thresholds, and 16 genera at the $97 \%$ threshold (Figure 7 ). It is noted that the two genera which were not discriminated by the V5-V7 region at the $97 \%$ threshold were Aminobacter and Mesorhizobium, suggesting that a threshold higher than the classical 97\% should be used when targeting these two genera in HTAS analyses. 


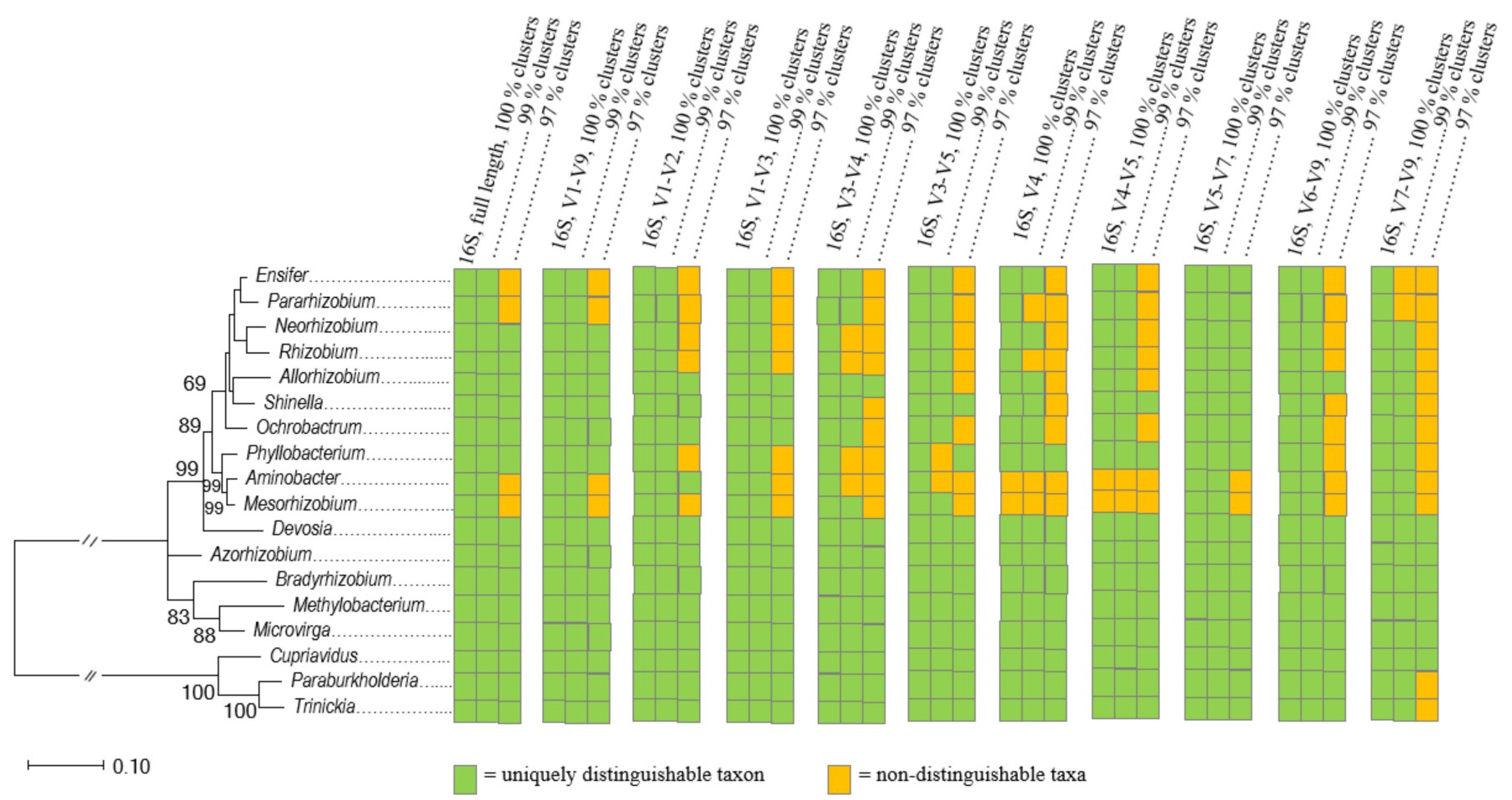

Figure 7. An unrooted phylogenetic tree based on the full-size sequence of the 16S rDNA (1564 positions), using the Maximum Likelihood method and Tamura-Nei model using a discrete Gamma distribution with invariant sites (TN93+G+I). Bootstrap values $\geq 70 \%$ based on 1000 replicates are indicated, and the scale bar represents the number of substitutions per site. A green shaded box indicates that a taxon can be uniquely distinguished with the given V-region and gene length and clustering method, while an orange box indicates that a taxon is merged with at least one other taxon in at least one gene cluster.

\section{Discussion}

A few studies reporting a characterization of soil rhizobial communities using the HTAS of $16 \mathrm{~S}$ rDNA variable regions were carried out in temperate arable soils in East Europe [45] and coniferous forest soils in North America [41]. Up to now, little is known of the soil microbiome of semiarid areas commonly known as savannahs [116,117], although there are considered important biodiversity hotspots, including for microorganisms $[118,119]$. Two examples of savannah biomes have been neglected in terms of research in microbial ecology for decades: the Brazilian Cerrado savannah and the African savannah $[116,120,121]$. The microbiome of the Cerrado savannah is relatively more explored, including for Archaea [122], Bacteria [118,123], Fungi [124] and Protists [125], unlike that of the African savannah, which has not been studied in a systematic manner $[35,48,126]$. The current study is among the pioneer studies on African savannahs microbiome [35,127], and it provides new insights into the presence and distribution of taxa of rhizobia across the Sudanian and the Sub-Sudanian savannah zones. It revealed that the rhizobial diversity in the savannah zones in Northern Côte d'Ivoire is considerable in terms of richness and relative abundance of genera and families detected. These findings are similar to those observed in the Brazilian Cerrado savannah [118,123] and the African Miombo Woodlands in Mozambique [127], where rhizobacteria, including rhizobia, were found genetically diversified and abundant $[118,127]$. However, these results contrast with a similar study carried out in the Mopane woodlands, another important savannah ecosystem in southern Africa [35].

Of the 18 Alpha- and Beta-proteobacterial genera harboring the described rhizobial species, only Allorhizobium, Aminobacter, Azorhizobium, Ochrobactrum, Pararhizobium and Phyllobacterium were not detected in soils from the savannah zones in Northern Côte $\mathrm{d}$ 'Ivoire. As these six genera have also a low relative number of validly published species 
to date, all these data suggested that they are probably less abundant and diversified in soils and/or are associated with a limited set of legumes species. From all the 12 genera detected, Bradyrhizobium was found more abundant and ubiquitous, together with Microvirga and Paraburkholderia. Contrasting findings have been reported on the prevalence, genetic diversity and the ubiquity of these three genera of rhizobia. An HTAS study of the potential nitrogen-fixing bacteria in Polish soils detected Devosia, Mesorhizobium, Methylobacterium, Microvirga, Phyllobacterium, and Rhizobium (alpha-rhizobia), as well as Burkholderia sensu lato (s.l.) and Cupriavidus (beta-rhizobia), but noted the absence of Bradyrhizobium [45]. In contrast to Wolińska et al. [45], a recent atlas established for dominant soil bacteria classified Bradyrhizobium and Devosia among the most abundant and ubiquitous bacteria worldwide, with an apparent paucity of Burkholderia s.l in soils [6]. Nevertheless, a survey of the top 20 most abundant genera found in soil samples revealed that Bradyrhizobium and Burkholderia s.l. are, respectively, the first and the second most prevalent genera of soil bacteria [128]. Although all these data indicated that Bradyrhizobium and/or Burkholderia s.l. and/or Microvirga were frequently detected among the most dominant bacteria genera in soil samples, to our knowledge, the current study is the first showing that the Bradyrhizobium genus dominates in tropical savannah soils, together with Microvirga and Paraburkholderia. The predominance and the ubiquity of rhizobia genera, including Bradyrhizobium and Burkholderia s.l., is thought to be due to their genetic diversity, and their catabolic versatility that enables them to degrade recalcitrant compounds and survive in oligotrophic environments [41,129,130]. Since Moulin et al. [131] described two Burkholderia nodule-forming strains isolated in French Guiana and in South Africa, beta-rhizobia have been routinely identified from soils, mainly in South Africa, South America and southeast Asia [40]. Some of these studies even reported the dominance of Paraburkholderia when compared to cosmopolitan Bradyrhizobium in several soils, depending on the biome (e.g., the Cerrado, Caatinga and Forest Atlantic biomes in Brazil; the Fynbos biome in South Africa), the legumes species (Mimosa spp.; Lebeckia spp.) and the soil types [39,40,104,132]. Several studies have demonstrated that the beta-rhizobia are well adapted to poor and acidic soils $[37,133,134]$. Our study suggests that Paraburkholderia and Trinickia are more abundant in the mildly acidic soils ( $\mathrm{pH} 5.7<\mathrm{pH}<6.0$ ), all of which harbored anthropogenic activities (fields of cashew and cereals etc.). Despite this observation in the cultivated soils, the impact of the savannah types on the dynamics of rhizobia diversity and abundance was not established in this study.

Although the variable regions of the $16 \mathrm{~S}$ rRNA gene (e.g., individual V-regions, adjacent V-regions, pairs of non-contiguous V-regions) are well known $[106,135,136]$, the selection of the most efficient variable region (s) for microbiome analysis is still debated $[63,106,107,110,137-139]$. Many studies indicated that the efficiency of the variable regions for HTAS analysis depends on multiple parameters, including the microorganisms of interest and the extent to which their $16 S$ rRNA genes have evolved [105,140,141]. For rhizobia, our study suggested that the V5-V7 region could be suitable for differentiating strains at the genus level, possibly replacing the use of the V4-V5 region. In a previous study, Eardly et al. [142] identified the V7 region alone as highly polymorphic in the Rhizobiales. Taken together, we suggest that the V5-V7 region contains sufficiently polymorphic DNA sequences to resolve the genetic complexity of the full 16S rRNA gene in rhizobia.

Many studies had reported the use of single-copy housekeeping genes in microbiome analyses to improve resolution at species and subspecies levels [143-147]. A multigenic approach that includes at least one housekeeping gene (e.g., rpoB) and one variable region of the 16S rRNA gene [148] is also considered a promising methodology. Taking into account these recommendations, we further propose the use of the V5-V7 region to analyze the rhizobial microbiome in combination with one of the four housekeeping genes ( $a t p D$ gyrB-recA-rpoB) that have been used for resolving ambiguous cases of identification among Rhizobium strains [149]. 
Supplementary Materials: The following are available online at https: / www.mdpi.com/article/ 10.3390/microorganisms9091842/s1, Figure S1: Covering area of each sampling site and its corresponding features, Figure S2: Rarefaction curve of the seven samples, indicated by the number of ASVs depending on the size of the sequence sample, Figure S3: 16S rDNA V4-V5 phylogenetic tree showing the relationship between all selected reference alpha and beta-rhizobia strains and the 77 ASVs detected in savannah soils of Northern Côte d'Ivoire, Table S1: Physico-chemical properties of samples soils, Table S2: Levels of similarity between the V4-V5 sequences of the 77 ASVs of rhizobia and all 18 alphaproteobacterial and betaproteobacterial genera harboring rhizobia strains, Table S3: Major characteristics of the 77 ASVs of rhizobia detected in savannah soils of Northern Côte d'Ivoire, Table S4: ASVs and their corresponding md5_hash identities, Table S5: ASVs richness, cumulative relative abundance of sequences and prevalence of ASVs per soil, Table S6: Measure of the richness and the alpha diversity per savannah zone.

Author Contributions: Conceptualization, D.A.C. and A.Z.; methodology, D.A.C., A.Z. and R.K.F.; software, A.E., D.K.K., C.G.Z.K., R.K.F., S.L.E.G. and. C.E.R.A.; validation, R.K.F.; formal analysis, A.E., R.K.F., S.L.E.G. and C.E.R.A.; data curation, R.K.F.; writing-original draft preparation, R.K.F.; writing-review and editing, A.Z., R.K.F., D.A.C., A.E., D.K.K., S.L.E.G.; C.E.R.A.; supervision, D.A.C. and A.Z.; project administration, D.A.C. and A.Z.; funding acquisition, D.A.C. All authors have read and agreed to the published version of the manuscript.

Funding: This research was funded by the US Agency for International Development (USAID), grant number 674-AA-2010-A1.

Institutional Review Board Statement: Not applicable.

Informed Consent Statement: Not applicable.

Data Availability Statement: The high-throughput amplicon sequencing reads of the 16S rRNA gene used in this study are available in the NCBI SRA database under accession numbers SRR13623317, SRR13623319, SRR13623320, SRR13623323, SRR13623324, SRR13623326 and SRR13623335.

Acknowledgments: We are grateful to EBINI N'guessan Janvier Bienvenu (Département de Géographie, Université Alassane Ouattara (UAO) de Bouaké, Bouaké, Côte d'Ivoire) for his help in generating Figure 1.

Conflicts of Interest: The authors declare no conflict of interest.

\section{References}

1. Nannipieri, P.; Ascher-jenull, J.; Ceccherini, M.T.; Pietramellara, G.; Renella, G.; Schloter, M. Beyond Microbial Diversity for Predicting Soil Functions: A Mini Review. Pedosphere 2020, 30, 5-17. [CrossRef]

2. Tedersoo, L.; Bahram, M.; Põlme, S.; Kõljalg, U.; Yorou, N.S.; Wijesundera, R.; Ruiz, L.V.; Vasco-Palacios, A.M.; Thu, P.Q.; Suija, A.; et al. Global Diversity and Geography of Soil Fungi. Science 2014, 346. [CrossRef]

3. Nelson, M.B.; Martiny, A.C.; Martiny, J.B.H. Global Biogeography of Microbial Nitrogen-Cycling Traits in Soil. Proc. Natl. Acad. Sci. USA 2016, 113, 8033-8040. [CrossRef] [PubMed]

4. Thompson, L.R.; Sanders, J.G.; McDonald, D.; Amir, A.; Ladau, J.; Locey, K.J.; Prill, R.J.; Tripathi, A.; Gibbons, S.M.; Ackermann, G.; et al. A Communal Catalogue Reveals Earth's Multiscale Microbial Diversity. Nature 2017, 551, 457-463. [CrossRef]

5. Bahram, M.; Hildebrand, F.; Forslund, S.K.; Anderson, J.L.; Soudzilovskaia, N.A.; Bodegom, P.M.; Bengtsson-Palme, J.; Anslan, S.; Coelho, L.P.; Harend, H.; et al. Structure and Function of the Global Topsoil Microbiome. Nature 2018, 560, 233-237. [CrossRef]

6. Delgado-Baquerizo, M.; Oliverio, A.M.; Brewer, T.E.; Benavent-González, A.; Eldridge, D.J.; Bardgett, R.D.; Maestre, F.T.; Singh, B.K.; Fierer, N. A Global Atlas of the Dominant Bacteria Found in Soil. Science 2018, 359, 320-325. [CrossRef]

7. Karimi, B.; Terrat, S.; Dequiedt, S.; Saby, N.P.A.; Horrigue, W.; Lelièvre, M.; Nowak, V.; Jolivet, C.; Arrouays, D.; Wincker, P.; et al. Biogeography of Soil Bacteria and Archaea across France. Sci. Adv. 2018, 4, eaat1808. [CrossRef]

8. Wild, S. Quest to Map Africa's Soil Microbiome Begins. Nat. News 2016, 539, 152. [CrossRef]

9. Cowan, D. The African Soil Microbiology Project, BMIF-FBIP Workshop, 14-17 August 2017. Available online: Http:// Biodiversityadvisor.Sanbi.Org/Wp-Content/Uploads/2018/01/5.The-African-Soil-Microbiology-Project_Durban-1.Pdf (accessed on 21 August 2021).

10. Bach, E. African Soil Microbiology Project. Available online: https://www.globalsoilbiodiversity.org/blog-beneath-our-feet/20 16/10/20/african-soil-microbiology-project (accessed on 18 December 2020).

11. Herridge, D.F.; Peoples, M.B.; Boddey, R.M. Global Inputs of Biological Nitrogen Fixation in Agricultural Systems. Plant Soil 2008, 311, 1-18. [CrossRef] 
12. De Lajudie, P.M.; Young, J.P.W. International Committee on Systematics of Prokaryotes Subcommittee for the Taxonomy of Rhizobium and Agrobacterium Minutes of the Meeting, Budapest, 25 August 2016. Int. J. Syst. Evol. Microbiol. 2017, 67, $2485-2494$. [CrossRef]

13. Raymond, J.; Siefert, J.L.; Staples, C.R.; Blankenship, R.E. The Natural History of Nitrogen Fixation. Mol. Biol. Evol. 2004, 21, 541-554. [CrossRef]

14. Boyd, E.; Peters, J.W. New Insights into the Evolutionary History of Biological Nitrogen Fixation. Front. Microbiol. 2013, 4. [CrossRef] [PubMed]

15. De Lajudie, P.M.; Andrews, M.; Ardley, J.; Eardly, B.; Jumas-Bilak, E.; Kuzmanović, N.; Lassalle, F.; Lindström, K.; Mhamdi, R.; Martínez-Romero, E.; et al. Minimal Standards for the Description of New Genera and Species of Rhizobia and Agrobacteria. Int. J. Syst. Evol. Microbiol. 2019, 69, 1852-1863. [CrossRef] [PubMed]

16. Perret, X.; Staehelin, C.; Broughton, W.J. Molecular Basis of Symbiotic Promiscuity. Microbiol. Mol. Biol. Rev. 2000, 64, 180-201. [CrossRef]

17. Oldroyd, G.E.D.; Downie, J.A. Coordinating Nodule Morphogenesis with Rhizobial Infection in Legumes. Annu. Rev. Plant Biol. 2008, 59, 519-546. [CrossRef] [PubMed]

18. Poole, P.; Ramachandran, V.; Terpolilli, J. Rhizobia: From Saprophytes to Endosymbionts. Nat. Rev. Microbiol. 2018, 16, 291-303. [CrossRef]

19. Sprent, J.I.; Ardley, J.; James, E.K. Biogeography of Nodulated Legumes and Their Nitrogen-Fixing Symbionts. New Phytol. 2017, 215, 40-56. [CrossRef]

20. Hördt, A.; López, M.G.; Meier-Kolthoff, J.P.; Schleuning, M.; Weinhold, L.-M.; Tindall, B.J.; Gronow, S.; Kyrpides, N.C.; Woyke, T.; Göker, M. Analysis of 1,000+ Type-Strain Genomes Substantially Improves Taxonomic Classification of Alphaproteobacteria. Front. Microbiol. 2020, 11. [CrossRef]

21. Parte, A.C.; Sardà Carbasse, J.; Meier-Kolthoff, J.P.; Reimer, L.C.; Göker, M. List of Prokaryotic Names with Standing in Nomenclature (LPSN) Moves to the DSMZ. Int. J. Syst. Evol. Microbiol. 2020, 70, 5607-5612. [CrossRef]

22. Tindall, B.J. The Name Bradyrhizobiaceae Garrity et al. 2006 Contains Nitrobacter Winogradsky 1892 (Approved Lists 1980), the Nomenclatural Type of the Family Nitrobacteraceae Buchanan 1917 (Approved Lists 1980), Is Illegitimate and Proposals to Alter the Wording of Rule 54 of the International Code of Nomenclature of Prokaryotes to Clarify the Fact That the Family Name Bradyrhizobiaceae Garrity et al. 2006 Is Replaced by the Family Name Nitrobacteraceae Buchanan 1917 (Approved Lists 1980) the Only Correct Name. Int. J. Syst. Evol. Microbiol. 2019, 69, 2609-2611. [CrossRef]

23. Jordan, D.C. Notes: Transfer of Rhizobium Japonicum Buchanan 1980 to Bradyrhizobium Gen. Nov., a Genus of Slow-Growing, Root Nodule Bacteria from Leguminous Plants. Int. J. Syst. Evol. Microbiol. 1982, 32, 136-139. [CrossRef]

24. Norris, D.O. Acid Production by Rhizobium a Unifying Concept. Plant Soil 1965, 22, 143-166. [CrossRef]

25. Hungria, M.; Menna, P.; Delamuta, J.R.M. Bradyrhizobium, the ancestor of all rhizobia: Phylogeny of housekeeping and nitrogen-fixation genes. In Biological Nitrogen Fixation; de Bruijn, F.J., Ed.; John Wiley \& Sons, Ltd.: Hoboken, NJ, USA, 2015; pp. 191-202.

26. Wang, S.; Meade, A.; Lam, H.-M.; Luo, H. Evolutionary Timeline and Genomic Plasticity Underlying the Lifestyle Diversity in Rhizobiales. mSystems 2020, 5. [CrossRef] [PubMed]

27. Frank, B. Ueber Die Pilzsymbiose Der Leguminosen. Berichte Dtsch. Bot. Ges. 1889, 7, 332-346. [CrossRef]

28. Lindström, K.; Mousavi, S.A. Effectiveness of Nitrogen Fixation in Rhizobia. Microb. Biotechnol. 2020, 13, 1314-1335. [CrossRef] [PubMed]

29. Grönemeyer, J.L.; Reinhold-Hurek, B. Diversity of Bradyrhizobia in Subsahara Africa: A Rich Resource. Front. Microbiol. 2018, 9. [CrossRef]

30. Jaiswal, S.K.; Dakora, F.D. Widespread Distribution of Highly Adapted Bradyrhizobium Species Nodulating Diverse Legumes in Africa. Front. Microbiol. 2019, 10. [CrossRef]

31. N'Zoué, A.A. Diversité génétique et fonctionnelle des souches de Bradyrhizobium impliquées dans les cultures mixtes niébé-sojaarachide/céréales (maïs) en Côte d'Ivoire: Approche méthodologique par analyse multi-locus (MLSA): Étude des effets PGPR sur le maïs. Ph.D. Thesis, Montpellier 2 University, Montpellier, France, 2008.

32. Fossou, R.K.; Ziegler, D.; Zézé, A.; Barja, F.; Perret, X. Two Major Clades of Bradyrhizobia Dominate Symbiotic Interactions with Pigeonpea in Fields of Côte d'Ivoire. Front. Microbiol. 2016, 7. [CrossRef]

33. Fossou, R.K.; Pothier, J.F.; Zézé, A.; Perret, X. Bradyrhizobium Ivorense Sp. Nov. as a Potential Local Bioinoculant for Cajanus Cajan Cultures in Côte d'Ivoire. Int. J. Syst. Evol. Microbiol. 2020, 70, 1421-1430. [CrossRef]

34. Fossou, R. Étude du système symbiotique rhizobia-Cajanus cajan dans des champs cultivés en Côte d'Ivoire. Ph.D. Thesis, Université de Genève, Genève, Switzerland, 2019.

35. Maquia, I.S.; Fareleira, P.; Videira e Castro, I.; Brito, D.R.A.; Soares, R.; Chaúque, A.; Ferreira-Pinto, M.M.; Lumini, E.; Berruti, A.; Ribeiro, N.S.; et al. Mining the Microbiome of Key Species from African Savanna Woodlands: Potential for Soil Health Improvement and Plant Growth Promotion. Microorganisms 2020, 8, 1291. [CrossRef]

36. Kosty, M.; Pule-Meulenberg, F.; Humm, E.A.; Martínez-Hidalgo, P.; Maymon, M.; Mohammadi, S.; Cary, J.; Yang, P.; Reddi, K.; Huntemann, M.; et al. Isolation of Potential Plant Growth-Promoting Bacteria from Nodules of Legumes Grown in Arid Botswana Soil. bioRxiv 2020. [CrossRef] 
37. Lemaire, B.; Chimphango, S.B.M.; Stirton, C.; Rafudeen, S.; Honnay, O.; Smets, E.; Chen, W.-M.; Sprent, J.; James, E.K.; Muasya, A.M. Biogeographical Patterns of Legume-Nodulating Burkholderia Spp.: From African Fynbos to Continental Scales. Appl. Environ. Microbiol. 2016, 82, 5099-5115. [CrossRef] [PubMed]

38. Singer, E.; Bushnell, B.; Coleman-Derr, D.; Bowman, B.; Bowers, R.M.; Levy, A.; Gies, E.A.; Cheng, J.-F.; Copeland, A.; Klenk, H.-P.; et al. High-Resolution Phylogenetic Microbial Community Profiling. ISME J. 2016, 10, 2020-2032. [CrossRef] [PubMed]

39. Beukes, C.W.; Boshoff, F.S.; Phalane, F.L.; Hassen, A.I.; le Roux, M.M.; Stępkowski, T.; Venter, S.N.; Steenkamp, E.T. Both Alphaand Beta-Rhizobia Occupy the Root Nodules of Vachellia Karroo in South Africa. Front. Microbiol. 2019, 10. [CrossRef]

40. Hassen, A.I.; Lamprecht, S.C.; Bopape, F.L. Emergence of $\beta$-Rhizobia as New Root Nodulating Bacteria in Legumes and Current Status of the Legume-Rhizobium Host Specificity Dogma. World J. Microbiol. Biotechnol. 2020, 36, 40. [CrossRef] [PubMed]

41. VanInsberghe, D.; Maas, K.R.; Cardenas, E.; Strachan, C.R.; Hallam, S.J.; Mohn, W.W. Non-Symbiotic Bradyrhizobium Ecotypes Dominate North American Forest Soils. ISME J. 2015, 9, 2435-2441. [CrossRef] [PubMed]

42. Garrido-Oter, R.; Nakano, R.T.; Dombrowski, N.; Ma, K.-W.; McHardy, A.C.; Schulze-Lefert, P. Modular Traits of the Rhizobiales Root Microbiota and Their Evolutionary Relationship with Symbiotic Rhizobia. Cell Host Microbe 2018, 24, 155-167.e5. [CrossRef] [PubMed]

43. Zhalnina, K.; de Quadros, P.D.; Gano, K.A.; Davis-Richardson, A.; Fagen, J.R.; Brown, C.T.; Giongo, A.; Drew, J.C.; Sayavedra-Soto, L.A.; Arp, D.J.; et al. Ca. Nitrososphaera and Bradyrhizobium Are Inversely Correlated and Related to Agricultural Practices in Long-Term Field Experiments. Front. Microbiol. 2013, 4. [CrossRef]

44. Hermans, S.M.; Buckley, H.L.; Case, B.S.; Curran-Cournane, F.; Taylor, M.; Lear, G. Using Soil Bacterial Communities to Predict Physico-Chemical Variables and Soil Quality. Microbiome 2020, 8, 79. [CrossRef] [PubMed]

45. Wolińska, A.; Kuźniar, A.; Zielenkiewicz, U.; Banach, A.; Izak, D.; Stępniewska, Z.; Błaszczyk, M. Metagenomic Analysis of Some Potential Nitrogen-Fixing Bacteria in Arable Soils at Different Formation Processes. Microb. Ecol. 2017, 73, 162-176. [CrossRef]

46. Ouattara, N. Situation des resources génétiques forestières de la Côte d'Ivoire (Zone de Savanes): Préparé pour l'atelier sous-régional FAO/IPGRI/CIRAF sur la conservation, la gestion, l'utilisation durable et la mise en valeur des ressources génétiques forestières de la zone sahélienne (Ouagadougou, 22-24 sept 1998); Service de la mise en valeur des ressources forestières, Division des ressources forestières; FAO: Rome, Italy, 2001.

47. Aregheore, E.M. Country Pasture/Forage Resource Profiles: Côte d'Ivoire 2009. Available online: https:/ / www.humanitarianlibrary. org/sites/default/files/2013/07/CotedIvoire-English.pdf (accessed on 19 December 2020).

48. Assémien, F.L.; Pommier, T.; Gonnety, J.T.; Gervaix, J.; Le Roux, X. Adaptation of Soil Nitrifiers to Very Low Nitrogen Level Jeopardizes the Efficiency of Chemical Fertilization in West African Moist Savannas. Sci. Rep. 2017, 7. [CrossRef]

49. Assémien, F.L.; Cantarel, A.A.M.; Florio, A.; Lerondelle, C.; Pommier, T.; Gonnety, J.T.; Le Roux, X. Different Groups of NitriteReducers and $\mathrm{N}_{2} \mathrm{O}$-Reducers Have Distinct Ecological Niches and Functional Roles in West African Cultivated Soils. Soil Biol. Biochem. 2019, 129, 39-47. [CrossRef]

50. USAID Country Profile: Côte d'Ivoire-Property Rights and Resource Governance. 2016. Available online: https:/ /www.landlinks.org/wp-content/uploads/2016/09/USAID_Land_Tenure_Cote_dIvoire_Profile.pdf (accessed on 22 June 2020).

51. Gautier, L. Contact Forêt-Savane En Côte d'Ivoire Centrale: Évolution de La Surface Forestière de La Réserve de Lamto (Sud Du V-Baoulé). Bull. Société Bot. Fr. Actual. Bot. 1989, 136, 85-92. [CrossRef]

52. Dugué, P.; Rodrigue Koné, F.; Koné, G. Gestion des ressources naturelles et évolution des systèmes de production agricole des savanes de Côte d'Ivoire: Conséquences pour l'élaboration des politiques agricoles. Cah. Agric. 2003, 12, 267-273. Available online: http:/ / revues.cirad.fr/index.php/cahiers-agricultures/article/view/30400 (accessed on 22 June 2020).

53. Guillaumet, J.-L.; Adjanohoun, E. La végétation de la Côte d'Ivoire. In Le milieu naturel de la Côte d'Ivoire; Avenard, J.-M., Eldin, M., Girard, G., Sircoulon, J., Touchebeuf de Lussigny, P., Guillaumet, J.-L., Adjanohoun, E., Perraud, A., Eds.; Mémoires ORSTOM; ORSTOM: Paris, France, 1971; pp. 161-263.

54. Diawara, A.; Yoroba, F.; Kouadio, K.Y.; Kouassi, K.B.; Assamoi, E.M.; Diedhiou, A.; Assamoi, P. Climate Variability in the Sudano-Guinean Transition Area and Its Impact on Vegetation: The Case of the Lamto Region in Côte D'Ivoire. Adv. Meteorol. 2014, 2014, e831414. [CrossRef]

55. Kone, N.; Asare-Bediako, E.; Koita, O.; Kone, D.; Winter, S. Seasonal and Spatial Variation in the Prevalence of Viral Diseases and Associated Aphid-Borne Viruses in Cucurbits in Cote d'Ivoire. Ann. Agric. Sci. 2017, 62, 227-234. [CrossRef]

56. Adjanohoun, E. Végétation des savanes et des rochers découverts en Côte d'Ivoire centrale; ORSTOM: Paris, France, 1964.

57. Gee, G.W.; Bauder, J.W. Particle-size analysis. In Methods of Soil Analysis, Part 1: Physical and Mineralogical Methods, 5.1.; Klute, A., Ed.; Soil Science Society of America Inc. and American Society of Agronomy Inc.: Madison, WI, USA, 1986 ; pp. 383-411.

58. Thomas, G.W. Soil pH and soil acidity. In Methods of Soil Analysis, Part 3: Chemical Methods, 5.3.; Sparks, D.L., Page, A.L., Helmke, P.A., Loeppert, R.H., Soltanpour, P.N., Tabatabai, M.A., Johnston, C.T., Sumner, M.E., Eds.; Soil Science Society of America Inc. and American Society of Agronomy Inc.: Madison, WI, USA, 1996; pp. 475-490.

59. Nelson, D.W.; Sommers, L.E. Total carbon, organic carbon, and organic matter. In Methods of Soil Analysis, Part 3: Chemical Methods, 5.3; Sparks, D.L., Page, A.L., Helmke, P.A., Loeppert, R.H., Soltanpour, P.N., Tabatabai, M.A., Johnston, C.T., Sumner, M.E., Eds.; Soil Science Society of America Inc. and American Society of Agronomy Inc.: Madison, WI, USA, 1996; pp. 961-1010.

60. Mehlich, A. Mehlich 3 Soil Test Extractant: A Modification of Mehlich 2 Extractant. Commun. Soil Sci. Plant Anal. 1984, 15, 1409-1416. [CrossRef] 
61. Nkuekam, G.K.; Cowan, D.A.; Valverde, A. Arable Agriculture Changes Soil Microbial Communities in the South African Grassland Biome. South Afr. J. Sci. 2018, 114. [CrossRef]

62. Parada, A.E.; Needham, D.M.; Fuhrman, J.A. Every Base Matters: Assessing Small Subunit RRNA Primers for Marine Microbiomes with Mock Communities, Time Series and Global Field Samples. Environ. Microbiol. 2016, 18, 1403-1414. [CrossRef]

63. Wang, Y.; Qian, P.-Y. Conservative Fragments in Bacterial 16S RRNA Genes and Primer Design for 16S Ribosomal DNA Amplicons in Metagenomic Studies. PLoS ONE 2009, 4, e7401. [CrossRef]

64. Martin, M. Cutadapt Removes Adapter Sequences from High-Throughput Sequencing Reads. EMBnet.journal 2011, 17, 10-12. [CrossRef]

65. Callahan, B.J.; McMurdie, P.J.; Rosen, M.J.; Han, A.W.; Johnson, A.J.A.; Holmes, S.P. DADA2: High-Resolution Sample Inference from Illumina Amplicon Data. Nat. Methods 2016, 13, 581-583. [CrossRef] [PubMed]

66. Wang, Q.; Garrity, G.M.; Tiedje, J.M.; Cole, J.R. Naïve Bayesian Classifier for Rapid Assignment of RRNA Sequences into the New Bacterial Taxonomy. Appl. Environ. Microbiol. 2007, 73, 5261-5267. [CrossRef] [PubMed]

67. Camacho, C.; Coulouris, G.; Avagyan, V.; Ma, N.; Papadopoulos, J.; Bealer, K.; Madden, T.L. BLAST+: Architecture and Applications. BMC Bioinformatics 2009, 10, 421. [CrossRef] [PubMed]

68. Quast, C.; Pruesse, E.; Yilmaz, P.; Gerken, J.; Schweer, T.; Yarza, P.; Peplies, J.; Glöckner, F.O. The SILVA Ribosomal RNA Gene Database Project: Improved Data Processing and Web-Based Tools. Nucleic Acids Res. 2013, 41, D590-D596. [CrossRef] [PubMed]

69. Rogers, J.S.; Swofford, D.L. A Fast Method for Approximating Maximum Likelihoods of Phylogenetic Trees from Nucleotide Sequences. Syst. Biol. 1998, 47, 77-89. [CrossRef]

70. Saitou, N.; Nei, M. The Neighbor-Joining Method: A New Method for Reconstructing Phylogenetic Trees. Mol. Biol. Evol. 1987, 4, 406-425. [CrossRef]

71. Schwarz, G. Estimating the Dimension of a Model. Ann. Stat. 1978, 6, 461-464. [CrossRef]

72. Rashid, M.H.-O.; Young, J.P.W.; Everall, I.; Clercx, P.; Willems, A.; Santhosh Braun, M.; Wink, M. Average Nucleotide Identity of Genome Sequences Supports the Description of Rhizobium Lentis Sp. Nov., Rhizobium Bangladeshense Sp. Nov. and Rhizobium Binae Sp. Nov. from Lentil (Lens Culinaris) Nodules. Int. J. Syst. Evol. Microbiol. 2015, 65, 3037-3045. [CrossRef]

73. De Lajudie, P.; Laurent-Fulele, E.; Willems, A.; Torek, U.; Coopman, R.; Collins, M.D.; Kersters, K.; Dreyfus, B.; Gillis, M. Allorhizobium Undicola Gen. Nov., Sp. Nov., Nitrogen-Fixing Bacteria That Efficiently Nodulate Neptunia Natans in Senegal. Int. J. Syst. Evol. Microbiol. 1998, 48, 1277-1290. [CrossRef]

74. Urakami, T.; Araki, H.; Oyanagi, H.; Suzuki, K.-I.; Komagata, K. Transfer of Pseudomonas Aminovorans (Den Dooren de Jong 1926) to Aminobacter Gen. Nov. as Aminobacter Aminovorans Comb. Nov. and Description of Aminobacter Aganoensis Sp. Nov. and Aminobacter Niigataensis Sp. Nov. Int. J. Syst. Evol. Microbiol. 1992, 42, 84-92. [CrossRef]

75. Dreyfus, B.; Garcia, J.L.; Gillis, M. Characterization of Azorhizobium Caulinodans Gen. Nov., Sp. Nov., a Stem-Nodulating Nitrogen-Fixing Bacterium Isolated from Sesbania Rostrata. Int. J. Syst. Evol. Microbiol. 1988, 38, 89-98. [CrossRef]

76. Estrada-de Los Santos, P.; Palmer, M.; Chávez-Ramírez, B.; Beukes, C.; Steenkamp, E.T.; Briscoe, L.; Khan, N.; Maluk, M.; Lafos, M.; Humm, E.; et al. Whole Genome Analyses Suggests That Burkholderia Sensu Lato Contains Two Additional Novel Genera (Mycetohabitans Gen. Nov., and Trinickia Gen. Nov.): Implications for the Evolution of Diazotrophy and Nodulation in the Burkholderiaceae. Genes 2018, 9, 389. [CrossRef]

77. Rivas, R.; Willems, A.; Subba-Rao, N.S.; Mateos, P.F.; Dazzo, F.B.; Kroppenstedt, R.M.; Martínez-Molina, E.; Gillis, M.; Velázquez, E. Description of Devosia Neptuniae Sp. Nov. That Nodulates and Fixes Nitrogen in Symbiosis with Neptunia Natans, an Aquatic Legume from India. Syst. Appl. Microbiol. 2003, 26, 47-53. [CrossRef] [PubMed]

78. Willems, A.; Fernández-López, M.; Muñoz-Adelantado, E.; Goris, J.; De Vos, P.; Martínez-Romero, E.; Toro, N.; Gillis, M. Description of New Ensifer Strains from Nodules and Proposal to Transfer Ensifer Adhaerens Casida 1982 to Sinorhizobium as Sinorhizobium Adhaerens Comb. Nov. Request for an Opinion. Int. J. Syst. Evol. Microbiol. 2003, 53, 1207-1217. [CrossRef] [PubMed]

79. Jarvis, B.D.W.; Pankhurst, C.E.; Patel, J.J. Rhizobium Loti, a New Species of Legume Root Nodule Bacteria. Int. J. Syst. Evol. Microbiol. 1982, 32, 378-380. [CrossRef]

80. Jarvis, B.D.W.; Van Berkum, P.; Chen, W.X.; Nour, S.M.; Fernandez, M.P.; Cleyet-Marel, J.C.; Gillis, M. Transfer of Rhizobium Loti, Rhizobium Huakuii, Rhizobium Ciceri, Rhizobium Mediterraneum, and Rhizobium Tianshanense to Mesorhizobium Gen. Nov. Int. J. Syst. Evol. Microbiol. 1997, 47, 895-898. [CrossRef]

81. Patt, T.E.; Cole, G.C.; Hanson, R.S. Methylobacterium, a New Genus of Facultatively Methylotrophic Bacteria. Int. J. Syst. Evol. Microbiol. 1976, 26, 226-229. [CrossRef]

82. Kanso, S.; Patel, B.K.C. Microvirga Subterranea Gen. Nov., Sp. Nov., a Moderate Thermophile from a Deep Subsurface Australian Thermal Aquifer. Int. J. Syst. Evol. Microbiol. 2003, 53, 401-406. [CrossRef]

83. Lindström, K. Rhizobium Galegae, a New Species of Legume Root Nodule Bacteria. Int. J. Syst. Evol. Microbiol. 1989, 39, 365-367. [CrossRef]

84. Mousavi, S.A.; Österman, J.; Wahlberg, N.; Nesme, X.; Lavire, C.; Vial, L.; Paulin, L.; de Lajudie, P.; Lindström, K. Phylogeny of the Rhizobium-Allorhizobium-Agrobacterium Clade Supports the Delineation of Neorhizobium Gen. Nov. Syst. Appl. Microbiol. 2014, 37, 208-215. [CrossRef]

85. Holmes, B.; Popoff, M.; Kiredjian, M.; Kersters, K. Ochrobactrum Anthropi Gen. Nov., Sp. Nov. from Human Clinical Specimens and Previously Known as Group Vd. Int. J. Syst. Evol. Microbiol. 1988, 38, 406-416. [CrossRef] 
86. Trujillo, M.E.; Willems, A.; Abril, A.; Planchuelo, A.-M.; Rivas, R.; Ludeña, D.; Mateos, P.F.; Martínez-Molina, E.; Velázquez, E. Nodulation of Lupinus Albus by Strains of Ochrobactrum Lupini Sp. Nov. Appl. Environ. Microbiol. 2005, 71, 1318-1327. [CrossRef]

87. Viallard, V.; Poirier, I.; Cournoyer, B.; Haurat, J.; Wiebkin, S.; Ophel-Keller, K.; Balandreau, J. Burkholderia Graminis Sp. Nov., a Rhizospheric Burkholderia Species, and Reassessment of [Pseudomonas] Phenazinium, [Pseudomonas] Pyrrocinia and [Pseudomonas] Glathei as Burkholderia. Int. J. Syst. Evol. Microbiol. 1998, 48, 549-563. [CrossRef]

88. Sawana, A.; Adeolu, M.; Gupta, R.S. Molecular Signatures and Phylogenomic Analysis of the Genus Burkholderia: Proposal for Division of This Genus into the Emended Genus Burkholderia Containing Pathogenic Organisms and a New Genus Paraburkholderia Gen. Nov. Harboring Environmental Species. Front. Genet. 2014, 5, 429. [CrossRef]

89. Amarger, N.; Macheret, V.; Laguerre, G. Rhizobium Gallicum Sp. Nov. and Rhizobium Giardinii Sp. Nov., from Phaseolus Vulgaris Nodules. Int. J. Syst. Evol. Microbiol. 1997, 47, 996-1006. [CrossRef]

90. Mousavi, S.A.; Willems, A.; Nesme, X.; de Lajudie, P.; Lindström, K. Revised Phylogeny of Rhizobiaceae: Proposal of the Delineation of Pararhizobium Gen. Nov., and 13 New Species Combinations. Syst. Appl. Microbiol. 2015, 38, 84-90. [CrossRef] [PubMed]

91. Jiao, Y.S.; Yan, H.; Ji, Z.J.; Liu, Y.H.; Sui, X.H.; Zhang, X.X.; Wang, E.T.; Chen, W.X.; Chen, W.F. Phyllobacterium Sophorae Sp. Nov., a Symbiotic Bacterium Isolated from Root Nodules of Sophora Flavescens. Int. J. Syst. Evol. Microbiol. 2015, 65, 399-406. [CrossRef] [PubMed]

92. An, D.-S.; Im, W.-T.; Yang, H.-C.; Lee, S.-T. Shinella Granuli Gen. Nov., Sp. Nov., and Proposal of the Reclassification of Zoogloea Ramigera ATCC 19623 as Shinella Zoogloeoides Sp. Nov. Int. J. Syst. Evol. Microbiol. 2006, 56, 443-448. [CrossRef] [PubMed]

93. Oren, A.; Garrity, G. List of New Names and New Combinations Previously Effectively, but Not Validly, Published. Int. J. Syst. Evol. Microbiol. 2020, 70, 1443-1446. [CrossRef] [PubMed]

94. Taulé, C.; Zabaleta, M.; Mareque, C.; Platero, R.; Sanjurjo, L.; Sicardi, M.; Frioni, L.; Battistoni, F.; Fabiano, E. New Betaproteobacterial Rhizobium Strains Able to Efficiently Nodulate Parapiptadenia Rigida (Benth.) Brenan. Appl. Environ. Microbiol. 2012, 78, 1692-1700. [CrossRef] [PubMed]

95. R Core Team (2020). R: A Language and Environment for Statistical Computing. R Foundation for Statistical Computing, Vienna, Austria. Available online: https:/ / www.eea.europa.eu/data-and-maps/indicators/oxygen-consuming-substances-in-rivers / r-development-core-team-2006 (accessed on 29 December 2020).

96. Oksanen, J.; Blanchet, F.G.; Friendly, M.; Kindt, R.; Legendre, P.; McGlinn, D.; Minchin, P.R.; O’Hara, R.B.; Simpson, G.L.; Solymos, P.; et al. Vegan: Community Ecology Package. Ordination Methods, Diversity Analysis and Other Functions for Community and Vegetation Ecologists. R Package Version 2.5-6 2019. Available online: https: / CRAN.R-project.org/package=vegan (accessed on 10 October 2020).

97. McMurdie, P.J.; Holmes, S. Phyloseq: An R Package for Reproducible Interactive Analysis and Graphics of Microbiome Census Data. PLoS ONE 2013, 8, e61217. [CrossRef] [PubMed]

98. Wickham, H. Ggplot2 - Elegant Graphics for Data Analysis (2nd Edition). J. Stat. Softw. 2017, 77. [CrossRef]

99. Hurlbert, S.H. The Nonconcept of Species Diversity: A Critique and Alternative Parameters. Ecology 1971, 52, 577-586. [CrossRef]

100. Rajaram, S.; Oono, Y. NeatMap - Non-Clustering Heat Map Alternatives in R. BMC Bioinformatics 2010, 11, 45. [CrossRef]

101. Parte, A.C. LPSN - List of Prokaryotic Names with Standing in Nomenclature (Bacterio.Net), 20 Years On. Int. J. Syst. Evol. Microbiol. 2018, 68, 1825-1829. [CrossRef]

102. Stępkowski, T.; Banasiewicz, J.; Granada, C.E.; Andrews, M.; Passaglia, L.M.P. Phylogeny and Phylogeography of Rhizobial Symbionts Nodulating Legumes of the Tribe Genisteae. Genes 2018, 9, 163. [CrossRef]

103. De Meyer, S.E.; Cnockaert, M.; Moulin, L.; Howieson, J.G.; Vandamme, P. Symbiotic and Non-Symbiotic Paraburkholderia Isolated from South African Lebeckia Ambigua Root Nodules and the Description of Paraburkholderia Fynbosensis Sp. Nov. Int. J. Syst. Evol. Microbiol. 2018, 68, 2607-2614. [CrossRef]

104. Paulitsch, F.; Delamuta, J.R.M.; Ribeiro, R.A.; da Silva Batista, J.S.; Hungria, M. Phylogeny of Symbiotic Genes Reveals Symbiovars within Legume-Nodulating Paraburkholderia Species. Syst. Appl. Microbiol. 2020, 43, 126151. [CrossRef] [PubMed]

105. Johnson, J.S.; Spakowicz, D.J.; Hong, B.-Y.; Petersen, L.M.; Demkowicz, P.; Chen, L.; Leopold, S.R.; Hanson, B.M.; Agresta, H.O.; Gerstein, M.; et al. Evaluation of 16S RRNA Gene Sequencing for Species and Strain-Level Microbiome Analysis. Nat. Commun. 2019, 10, 5029. [CrossRef]

106. Baker, G.C.; Smith, J.J.; Cowan, D.A. Review and Re-Analysis of Domain-Specific 16S Primers. J. Microbiol. Methods 2003, 55, 541-555. [CrossRef]

107. Kim, M.; Morrison, M.; Yu, Z. Evaluation of Different Partial 16S RRNA Gene Sequence Regions for Phylogenetic Analysis of Microbiomes. J. Microbiol. Methods 2011, 84, 81-87. [CrossRef] [PubMed]

108. VanInsberghe, D.; Arevalo, P.; Chien, D.; Polz, M.F. How Can Microbial Population Genomics Inform Community Ecology? Philos. Trans. R. Soc. B Biol. Sci. 2020, 375, 20190253. [CrossRef]

109. Katoh, K.; Standley, D.M. MAFFT Multiple Sequence Alignment Software Version 7: Improvements in Performance and Usability. Mol. Biol. Evol. 2013, 30, 772-780. [CrossRef] [PubMed]

110. Klindworth, A.; Pruesse, E.; Schweer, T.; Peplies, J.; Quast, C.; Horn, M.; Glöckner, F.O. Evaluation of General 16S Ribosomal RNA Gene PCR Primers for Classical and Next-Generation Sequencing-Based Diversity Studies. Nucleic Acids Res. 2013,41 , e1. [CrossRef] [PubMed]

111. Shine, J.; Dalgarno, L. The 3'-Terminal Sequence of Escherichia Coli 16S Ribosomal RNA: Complementarity to Nonsense Triplets and Ribosome Binding Sites. Proc. Natl. Acad. Sci. USA 1974, 71, 1342-1346. [CrossRef] 
112. Brosius, J.; Palmer, M.L.; Kennedy, P.J.; Noller, H.F. Complete Nucleotide Sequence of a 16S Ribosomal RNA Gene from Escherichia Coli. Proc. Natl. Acad. Sci. USA 1978, 75, 4801-4805. [CrossRef] [PubMed]

113. Blattner, F.R.; Plunkett, G.; Bloch, C.A.; Perna, N.T.; Burland, V.; Riley, M.; Collado-Vides, J.; Glasner, J.D.; Rode, C.K.; Mayhew, G.F.; et al. The Complete Genome Sequence of Escherichia Coli K-12. Science 1997, 277, 1453-1462. [CrossRef]

114. Erlacher, A.; Cernava, T.; Cardinale, M.; Soh, J.; Sensen, C.W.; Grube, M.; Berg, G. Rhizobiales as Functional and Endosymbiontic Members in the Lichen Symbiosis of Lobaria Pulmonaria L. Front. Microbiol. 2015, 6. [CrossRef]

115. Edgar, R.C. Updating the 97\% Identity Threshold for 16 S Ribosomal RNA OTUs. Bioinforma. Oxf. Engl. 2018, 34, 2371-2375. [CrossRef]

116. Macrae, A.; Coelho, R.R.R.; Peixoto, R.; Rosado, A.S. Tropical soil microbial communities. In The Prokaryotes - Prokaryotic Communities and Ecophysiology; Rosenberg, E., DeLong, E.F., Lory, S., Stackebrandt, E., Thompson, F., Eds.; Springer-Verlag: Berlin/Heidelberg, Germany, 2013; pp. 85-95.

117. Murphy, B.P.; Andersen, A.N.; Parr, C.L. The Underestimated Biodiversity of Tropical Grassy Biomes. Philos. Trans. R. Soc. B Biol. Sci. 2016, 371, 20150319. [CrossRef]

118. Araujo, J.F.; de Castro Pires, A.P.; Costa, M.M.; Togawa, R.C.; Júnior, G.J.P.; Quirino, B.F.; Bustamante, M.M.; Abbadie, L.; Handelsman, J.; Krüger, R.H. Characterization of Soil Bacterial Assemblies in Brazilian Savanna-like Vegetation Reveals Acidobacteria Dominance. Microb. Ecol. 2012, 64, 760-770. [CrossRef]

119. Delgado-Baquerizo, M.; Eldridge, D.J. Cross-Biome Drivers of Soil Bacterial Alpha Diversity on a Worldwide Scale. Ecosystems 2019, 22, 1220-1231. [CrossRef]

120. Bruce, T.; de Castro, A.; Kruger, R.; Thompson, C.C.; Thompson, F.L. Microbial diversity of Brazilian biomes. In Genomics Applications for the Developing World; Nelson, K.E., Jones-Nelson, B., Eds.; Springer: New York, NY, USA, 2012 ; pp. $217-247$.

121. De Castro, A.P.; da Silva, M.R.S.S.; Quirino, B.F.; da Cunha Bustamante, M.M.; Krüger, R.H. Microbial Diversity in Cerrado Biome (Neotropical Savanna) Soils. PLoS ONE 2016, 11, e0148785. [CrossRef]

122. De Araujo, A.S.F.; Mendes, L.W.; Bezerra, W.M.; Nunes, L.A.P.L.; Lyra, M.D.C.C.P.D.; Figueiredo, M.D.V.B.; Melo, V.M.M. Archaea Diversity in Vegetation Gradients from the Brazilian Cerrado. Braz. J. Microbiol. 2018, 49, 522-528. [CrossRef]

123. De Araujo, A.S.F.; Bezerra, W.M.; Dos Santos, V.M.; Rocha, S.M.B.; da Silva Carvalho, N.; de Lyra, M.D.C.C.P.; Figueiredo, M.D.V.B.; de Almeida Lopes, Â.C.; Melo, V.M.M. Distinct Bacterial Communities across a Gradient of Vegetation from a Preserved Brazilian Cerrado. Antonie Van Leeuwenhoek 2017, 110, 457-469. [CrossRef] [PubMed]

124. De Araujo, A.S.F.; Bezerra, W.M.; Dos Santos, V.M.; Nunes, L.A.P.L.; de Lyra, M.D.C.C.P.; Figueiredo, M.D.V.B.; Melo, V.M.M. Fungal Diversity in Soils across a Gradient of Preserved Brazilian Cerrado. J. Microbiol. Seoul Korea 2017, 55, 273-279. [CrossRef]

125. De Araujo, A.S.F.; Mendes, L.W.; Lemos, L.N.; Antunes, J.E.L.; Beserra, J.E.A.; de Lyra, M.D.C.C.P.; Figueiredo, M.D.V.B.; de Almeida Lopes, Â.C.; Gomes, R.L.F.; Bezerra, W.M.; et al. Protist Species Richness and Soil Microbiome Complexity Increase towards Climax Vegetation in the Brazilian Cerrado. Commun. Biol. 2018, 1, 135. [CrossRef] [PubMed]

126. Rughöft, S.; Herrmann, M.; Lazar, C.S.; Cesarz, S.; Levick, S.R.; Trumbore, S.E.; Küsel, K. Community Composition and Abundance of Bacterial, Archaeal and Nitrifying Populations in Savanna Soils on Contrasting Bedrock Material in Kruger National Park, South Africa. Front. Microbiol. 2016, 7. [CrossRef]

127. Maquia, I.S.A.; Fareleira, P.; Videira e. Castro, I.; Soares, R.; Brito, D.R.A.; Mbanze, A.A.; Chaúque, A.; Máguas, C.; Ezeokoli, O.T.; Ribeiro, N.S.; et al. The Nexus between Fire and Soil Bacterial Diversity in the African Miombo Woodlands of Niassa Special Reserve, Mozambique. Microorganisms 2021, 9, 1562. [CrossRef]

128. Shah, V.; Subramaniam, S. Bradyrhizobium Japonicum USDA110: A Representative Model Organism for Studying the Impact of Pollutants on Soil Microbiota. Sci. Total Environ. 2018, 624, 963-967. [CrossRef] [PubMed]

129. Suárez-Moreno, Z.R.; Caballero-Mellado, J.; Coutinho, B.G.; Mendonça-Previato, L.; James, E.K.; Venturi, V. Common Features of Environmental and Potentially Beneficial Plant-Associated Burkholderia. Microb. Ecol. 2012, 63, 249-266. [CrossRef] [PubMed]

130. Weigold, P.; El-Hadidi, M.; Ruecker, A.; Huson, D.H.; Scholten, T.; Jochmann, M.; Kappler, A.; Behrens, S. A Metagenomic-Based Survey of Microbial (de)Halogenation Potential in a German Forest Soil. Sci. Rep. 2016, 6, 28958. [CrossRef]

131. Moulin, L.; Munive, A.; Dreyfus, B.; Boivin-Masson, C. Nodulation of Legumes by Members of the Beta-Subclass of Proteobacteria. Nature 2001, 411, 948-950. [CrossRef]

132. Bontemps, C.; Elliott, G.N.; Simon, M.F.; Dos Reis Júnior, F.B.; Gross, E.; Lawton, R.C.; Neto, N.E.; de Fátima Loureiro, M.; De Faria, S.M.; Sprent, J.I.; et al. Burkholderia Species Are Ancient Symbionts of Legumes. Mol. Ecol. 2010, 19, 44-52. [CrossRef]

133. Garau, G.; Yates, R.J.; Deiana, P.; Howieson, J.G. Novel Strains of Nodulating Burkholderia Have a Role in Nitrogen Fixation with Papilionoid Herbaceous Legumes Adapted to Acid, Infertile Soils. Soil Biol. Biochem. 2009, 41, 125-134. [CrossRef]

134. De Castro Pires, R.; dos Reis Junior, F.B.; Zilli, J.E.; Fischer, D.; Hofmann, A.; James, E.K.; Simon, M.F. Soil Characteristics Determine the Rhizobia in Association with Different Species of Mimosa in Central Brazil. Plant Soil 2018, 423, 411-428. [CrossRef]

135. Gray, M.W.; Sankoff, D.; Cedergren, R.J. On the Evolutionary Descent of Organisms and Organelles: A Global Phylogeny Based on a Highly Conserved Structural Core in Small Subunit Ribosomal RNA. Nucleic Acids Res. 1984, 12, 5837-5852. [CrossRef]

136. Chakravorty, S.; Helb, D.; Burday, M.; Connell, N.; Alland, D. A Detailed Analysis of 16S Ribosomal RNA Gene Segments for the Diagnosis of Pathogenic Bacteria. J. Microbiol. Methods 2007, 69, 330-339. [CrossRef]

137. Pinna, N.K.; Dutta, A.; Monzoorul Haque, M.; Mande, S.S. Can Targeting Non-Contiguous V-Regions with Paired-End Sequencing Improve 16S RRNA-Based Taxonomic Resolution of Microbiomes?: An in Silico Evaluation. Front. Genet. 2019, 10, 653. [CrossRef] 
138. Yang, B.; Wang, Y.; Qian, P.-Y. Sensitivity and Correlation of Hypervariable Regions in 16S RRNA Genes in Phylogenetic Analysis. BMC Bioinformatics 2016, 17, 135. [CrossRef] [PubMed]

139. Wasimuddin; Schlaeppi, K.; Ronchi, F.; Leib, S.L.; Erb, M.; Ramette, A. Evaluation of Primer Pairs for Microbiome Profiling from Soils to Humans within the One Health Framework. Mol. Ecol. Resour. 2020, 20, 1558-1571. [CrossRef]

140. Apprill, A.; McNally, S.; Parsons, R.J.; Weber, L.K. Minor Revision to V4 Region SSU RRNA 806R Gene Primer Greatly Increases Detection of SAR11 Bacterioplankton. Aquat. Microb. Ecol. 2015. [CrossRef]

141. Eloe-Fadrosh, E.A.; Ivanova, N.N.; Woyke, T.; Kyrpides, N.C. Metagenomics Uncovers Gaps in Amplicon-Based Detection of Microbial Diversity. Nat. Microbiol. 2016, 1, 15032. [CrossRef] [PubMed]

142. Eardly, B.D.; Nour, S.M.; van Berkum, P.; Selander, R.K. Rhizobial 16S RRNA and DnaK Genes: Mosaicism and the Uncertain Phylogenetic Placement of Rhizobium Galegae. Appl. Environ. Microbiol. 2005, 71, 1328-1335. [CrossRef] [PubMed]

143. Schellenberg, J.; Links, M.G.; Hill, J.E.; Dumonceaux, T.J.; Peters, G.A.; Tyler, S.; Ball, T.B.; Severini, A.; Plummer, F.A. Pyrosequencing of the Chaperonin-60 Universal Target as a Tool for Determining Microbial Community Composition. Appl. Environ. Microbiol. 2009, 75, 2889-2898. [CrossRef]

144. Links, M.G.; Dumonceaux, T.J.; Hemmingsen, S.M.; Hill, J.E. The Chaperonin-60 Universal Target Is a Barcode for Bacteria That Enables de Novo Assembly of Metagenomic Sequence Data. PLoS ONE 2012, 7, e49755. [CrossRef]

145. Poirier, S.; Rué, O.; Peguilhan, R.; Coeuret, G.; Zagorec, M.; Champomier-Vergès, M.-C.; Loux, V.; Chaillou, S. Deciphering Intra-Species Bacterial Diversity of Meat and Seafood Spoilage Microbiota Using GyrB Amplicon Sequencing: A Comparative Analysis with 16S RDNA V3-V4 Amplicon Sequencing. PLoS ONE 2018, 13, e0204629. [CrossRef]

146. Schellenberg, J.; Links, M.G.; Hill, J.E.; Hemmingsen, S.M.; Peters, G.A.; Dumonceaux, T.J. Pyrosequencing of chaperonin-60 (cpn60) amplicons as a means of determining microbial community composition. In High-Throughput Next Generation Sequencing: Methods and Applications; Kwon, Y.M., Ricke, S.C., Eds.; Humana Press: Totowa, NJ, USA, 2011; Volume 733, pp. 143-158.

147. Barret, M.; Briand, M.; Bonneau, S.; Préveaux, A.; Valière, S.; Bouchez, O.; Hunault, G.; Simoneau, P.; Jacquesa, M.-A. Emergence Shapes the Structure of the Seed Microbiota. Appl. Environ. Microbiol. 2015, 81, 1257-1266. [CrossRef]

148. Ogier, J.-C.; Pagès, S.; Galan, M.; Barret, M.; Gaudriault, S. RpoB, a Promising Marker for Analyzing the Diversity of Bacterial Communities by Amplicon Sequencing. BMC Microbiol. 2019, 19, 171. [CrossRef]

149. Young, J.P.W.; Moeskjær, S.; Afonin, A.; Rahi, P.; Maluk, M.; James, E.K.; Cavassim, M.I.A.; Rashid, M.H.; Aserse, A.A.; Perry, B.J.; et al. Defining the Rhizobium Leguminosarum Species Complex. Genes 2021, 12, 111. [CrossRef] [PubMed] 